\title{
Synthesis, Crystal Structure, Inhibitory Activity and Molecular Docking of Coumarins/Sulfonamides Containing Triazolyl Pyridine Moiety as Potent Selective Carbonic Anhydrase IX and XII Inhibitors
}

\author{
Yassine Aimene 1,2,3, Romain Eychenne ${ }^{2,3}$, Frédéric Rodriguez ${ }^{2,3}$, Sonia Mallet-Ladeira ${ }^{4}$, \\ Nathalie Saffon-Merceron ${ }^{4}\left(\mathbb{D}\right.$, Jean-Yves Winum ${ }^{5}\left(\mathbb{D}\right.$, Alessio Nocentini ${ }^{6} \mathbb{D}$, Claudiu T. Supuran $^{6} \mathbb{D}^{D}$, \\ Eric Benoist ${ }^{2,3, *}$ and Achour Seridi ${ }^{1, *(D)}$
}

check for updates

Citation: Aimene, Y.; Eychenne, R.; Rodriguez, F.; Mallet-Ladeira, S.; Saffon-Merceron, N.; Winum, J.-Y.; Nocentini, A.; Supuran, C.T.; Benoist, E.; Seridi, A. Synthesis, Crystal Structure, Inhibitory Activity and Molecular Docking of Coumarins/Sulfonamides Containing Triazolyl Pyridine Moiety as Potent Selective Carbonic Anhydrase IX and XII Inhibitors. Crystals 2021, 11, 1076. https://doi.org/10.3390/ cryst11091076

Academic Editor: Paul R. Raithby

Received: 27 July 2021

Accepted: 31 August 2021

Published: 6 September 2021

Publisher's Note: MDPI stays neutral with regard to jurisdictional claims in published maps and institutional affiliations.

Copyright: (c) 2021 by the authors Licensee MDPI, Basel, Switzerland. This article is an open access article distributed under the terms and conditions of the Creative Commons Attribution (CC BY) license (https:// creativecommons.org/licenses/by/ $4.0 /)$
1 Laboratoire de Chimie Physique, Université 8 Mai 1945, B.P.401, Guelma 24000, Algeria; yassine.aimene@gmail.com

2 CNRS, Laboratoire de Synthèse et Physico-Chimie de Molécules d'Intérêt Biologique, SPCMIB, UMR 5068, 118, Route de Narbonne, CEDEX 09, F-31062 Toulouse, France; rom.eychenne@gmail.com (R.E.); build@chimie.ups-tlse.fr (F.R.)

3 Laboratoire de Synthèse et Physico-Chimie de Molécules d'Intérêt Biologique, SPCMIB, Université de Toulouse, UMR 5068, 118, Route de Narbonne, CEDEX 09, F-31062 Toulouse, France

4 Institut de Chimie de Toulouse (ICT-UAR 2599), 118 Route de Narbonne, CEDEX 09, F-31062 Toulouse, France; ladeira@chimie.ups-tlse.fr (S.M.-L.); saffon@chimie.ups-tlse.fr (N.S.-M.)

5 IBMM, University of Montpellier, CNRS, ENSCM, F-34296 Montpellier, France; jean-yves.winum@umontpellier.fr

6 Neurofarba Department, Section of Pharmaceutical and Nutriceutical Sciences, Università degli Studi di Firenze, Via Ugo Schiff 6, Sesto Fiorentino, 50019 Florence, Italy; alessio.nocentini@unifi.it (A.N.); claudiu.supuran@unifi.it (C.T.S.)

* Correspondence: benoist@chimie.ups-tlse.fr (E.B.); seridi_a@yahoo.fr or seridi.achour@univ-guelma.dz (A.S.); Tel.:+33-561556480 (E.B.); +21-3666821635 (A.S.)

Abstract: In this work, two classes of Carbonic Anhydrase (CA) inhibitors, sulfonamide and coumarin derivatives linked to pyta moiety (2a-b) and their corresponding rhenium complexes (3a-b), were designed. These compounds were synthesized and fully characterized by classical analytical methods and X-ray diffraction. All the synthesized compounds were evaluated for their inhibitory activity against the hCA isoforms I, II, IX and XII. They exhibited high inhibitory activities in the range of nanomolar for both hCA IX and hCA XII isoforms. The sulfonamide compound 2a showed the strongest inhibition against the tumour-associated hCA IX isoform with a Ki of $11.7 \mathrm{nM}$. The tumourassociated isoforms hCA IX and hCA XII were selectively inhibited by all the coumarin derivatives, with inhibition constants ranging from $12.7 \mathrm{nM}(\mathbf{2 b})$ to $44.5 \mathrm{nM}(3 \mathbf{b})$, while the hCA I and II isoforms were slightly inhibited (in the micromolar range), as expected. In terms of selectivity, compared to previously published rhenium complex-based CA inhibitors, complex $3 \mathbf{b}$ showed one of the highest selectivities against hCA IX and hCA XII compared to the off-target isoforms hCA I and hCA II, making it a potential anti-cancer drug candidate. Molecular docking calculations were performed to investigate the inhibition profiles of the investigated compounds at the tumour-associated hCA IX active site and to rationalize our results.

Keywords: coumarin; sulfonamide; rhenium(I) complex; crystal structure; carbonic anhydrase inhibitor; molecular docking

\section{Introduction}

Carbonic anhydrases (CAs, EC 4.2.1.1) are zinc-containing metalloenzymes that catalyze the reversible hydration of carbon dioxide into bicarbonate ions and protons, to maintain acid-base balance in tissues and blood. hCA IX, and XII are known to be highly 
expressed in various human tissues and malignancies [1]. In particular, hCA IX and XII isoenzymes are markers of disease progression in many hypoxic tumour types, and their inhibition has been shown to be associated with significant inhibition of both primary tumour growth and metastasis [2-6]. Inhibition of hCA IX activity by small organic molecule CA inhibitors belonging to the sulfonamide/coumarin family leads to a potential inhibition of tumorigenesis [7-9]. Sulfonamides and their bioisosters (sulfamates, sulfamides, etc.) were designed to act as potent CA inhibitors [10-13]. Most of them bind directly to the zinc active centre into the CA cavity [14]. This efficient anti-tumour mechanism makes them a promising class of available anti-cancer agents $[15,16]$.

Due to the structural homology between several hCA isoforms, the challenge is to design new compounds possessing both high inhibitory potency and high CA selectivity for specific isoforms [17]. To address this challenge, a number of recent works have proposed incorporating various metal complexes and sulfonamide scaffolds into a single compound to obtain novel potent and selective CA inhibitors [18-23]. Alberto's team, for example, studied some tricarbonyl rhenium(I) complexes, incorporating an aryl-sulfonamide arm for their CA inhibitory properties [23]. These rhenium(I) complexes showed a significant in vitro inhibitory effect, with high selectivity against tumour-associated hCA IX targets, implying that interactions between the $\left[\operatorname{Re}(\mathrm{CO})_{3}\right]^{+}$core and the amino acid residues of the CA active site cavity entrance could enhance the inhibitory potency. In this regard, in a recent paper, we investigated the inhibitory effects of two benzenesulfonamide-based 1,2,3-triazole-pyridine derivatives (so-called pyta) and their corresponding fac- $\operatorname{Re}(\mathrm{CO})_{3}$ coordination compounds on human cytosolic hCA isoforms I and II, and the membraneassociated hCA IX isoform [24]. Most of the synthesized compounds (organic ligands and metallic complexes) showed promising activity in the nanomolar range for hCA IX isozymes. More interestingly, one of these coordination compounds showed pronounced selectivity against hCA IX over the off-target isoforms, hCA I and hCA II [24]. These encouraging results motivated us to pursue our interest in exploring this interesting class of tricarbonyl rhenium(I) complexes as potential anti-cancer drugs.

Besides sulfonamide derivatives, coumarins were recently shown to constitute a totally new class of inhibitors of the zinc metalloenzyme carbonic anhydrase. Coumarins have a high selectivity against trans-membrane tumour-associated hCA IX and hCA XII isoforms, compared to the widespread cytosolic hCA I and II isoforms [17,25-29]. One explanation for this high selectivity against human isoforms IX and XII compared to I and II is that while the twelve catalytically-active human isoforms have a rather conserved active site, especially in the lower and median parts, the most variable region is at the entrance to the cavity, where many residues differ between the various isoforms. Moreover, in contrast to other CA inhibitors, coumarin derivatives have a different mechanism of inhibition than the sulfonamide classes. They interact in a hydrolyzed form with the side chain residues at the rim of the CA cavity, away from the zinc ion [30-32].

Given the remarkable activities of the diverse types of sulfonamide/coumarin CA inhibitors, and as a continuation of our previous studies in the field of potent carbonic anhydrase inhibitors based on tricarbonyl rhenium(I) complexes [24], we hypothesized that the substitution of the sulfonamide pharmacophore grafted to our rhenium complex with a coumarin derivative could improve both the activity and the selectivity of our drugs against hCA IX and also hCA XII isoforms. In the present study, we describe a convenient synthesis of two tricarbonyl rhenium(I) complexes, based on bidentate pyridine-triazole ligands functionalized either by the bioactive 4-substituted benzenesulfonamide or a coumarin moiety, and using an ethylene bridge as a spacer in order to minimize sterical interference between the metallic chelating centre and the pharmacophore. The synthesized compounds were prepared by classical copper-catalyzed Huisgen cycloaddition (CuAAC reaction) and fully characterized. Both ligands and their corresponding rhenium(I) complexes exhibited nanomolar affinities against cytosolic (hCA I and II) and the trans-membrane, tumour-associated (hCA IX and XII) isoforms. Better inhibition was observed for coumarin derivatives compared to their corresponding sulfonamide analogues, as anticipated. To 
rationalize our results, molecular docking calculations were also applied to investigate the inhibition profiles of the synthesized compounds at the tumour-associated hCA IX active site. Two different mechanisms of hCA inhibition are presented here: sulfonamide compounds (2a/3a) that bind directly to the zinc active site, and coumarin compounds $(\mathbf{2 b} / \mathbf{3 b})$ that block the entrance of the enzyme cavity in its closed (non-hydrolyzed) and hydrolyzed form.

\section{Materials and Methods}

\subsection{Materials and Equipment}

All purchased chemicals were of the highest purity (>99.9\%) commercially available and used without further purification. Analytical grade solvents were used and not further purified unless specified. 4-(2-aminoethyl)-benzenesulfonamide and 2-ethynylpyridine were purchased from Aldrich Chem. Co. (Aldrich France, St Quentin Fallavier, France). 7-hydroxy-4-methylumbelliferone and $\left[\operatorname{Re}(\mathrm{CO})_{5} \mathrm{Cl}\right]$ were purchased from Acros Organics (Fisher Scientific SAS, Illkirch, France).

Melting points ( $\mathrm{mp}$ ) were determined in open capillaries using a Mettler Toledo (VWR International SAS, Fontenay-sous-Bois, France) and are uncorrected. ${ }^{1} \mathrm{H}$ and ${ }^{13} \mathrm{C}$ nuclear magnetic resonance (NMR) spectra were recorded with a Bruker Avance 300 (75.5) MHz spectrometer (Bruker France SAS, Wissembourg, France) at room temperature using $\mathrm{CDCl}_{3}$ or DMSO- $\mathrm{d}_{6}$ as a solvent unless otherwise stated. Chemical shifts are reported in parts per million (ppm) relative to a residual solvent peak $\left(\mathrm{CDCl}_{3}:{ }^{1} \mathrm{H}: \delta 7.26,{ }^{13} \mathrm{C}: \delta 77.2 ; \mathrm{DMSO}-\mathrm{d}_{6}\right.$ : $\left.{ }^{1} \mathrm{H}: \delta 2.50,{ }^{13} \mathrm{C}: \delta 39.5\right)$ and coupling constants $(\mathrm{J})$ are given in Hertz $(\mathrm{Hz})$. Multiplicities were recorded as s (singlet), br s (broad singlet), d (doublet), t (triplet), q (quadruplet) and $\mathrm{m}$ (multiplet). Infrared (IR) spectra were recorded with a Perkin-Elmer FTIR 1725 spectrophotometer (VWR International SAS, Fontenay-sous-Bois, France) in the range 4000-400 $\mathrm{cm}^{-1}$. Electrospray (ESI) mass spectra were obtained on a Q TRAP Applied Biosystems spectrometer (Thermo-Fisher Scientific, Waltham, USA) and High-Resolution Mass Spectra (HRMS) on an LCT Premier Waters spectrometer (Waters SAS, Saint-Quentin en Yvelines, France). Microanalysis was performed by the microanalytical department of the Laboratoire de Chimie de Coordination de Toulouse (LCC, Toulouse, France). Electronic spectrum was measured on a Hewlett Packard 8453 temperature-controlled spectrometer in the range $1000-200 \mathrm{~nm}$ in methanol solution.

Literature methods were used to prepare intermediates 1a [33] and $\mathbf{1 b}$ [34] (it is known that azido compounds are potentially explosive intermediate products, however, we never observed suspicious reactions in this experimental procedure).

\subsection{Synthesis}

\subsubsection{Ligands Synthesis}

General Procedure: A mixture of the azido compound (1a or 1b, 1.1 eq.) and 2ethynylpyridine (1eq.) was suspended in acetonitrile (0.2-0.5 $\mathrm{M}$ final concentration). Copper(II) acetate monohydrate ( 0.2 eq.) and sodium ascorbate ( 0.4 eq.) were added and stirred in the dark at $45^{\circ} \mathrm{C}$ overnight. The reaction solvent was removed under reduced pressure and the remaining residues were purified by column chromatography on silica gel using $\mathrm{CH}_{2} \mathrm{Cl}_{2} / \mathrm{MeOH}$ (95:5 for $\mathbf{2} \mathbf{a}$ and $98: 2$ for $\mathbf{2} \mathbf{b}$ ) as eluent.

4-(4-(2-pyridyl)-1H-1,2,3-triazol-1-ylethyl)-benzenesulfonamide (2a)

$130 \mathrm{mg}(0.57 \mathrm{mmol})$ of $1 \mathrm{a}$ and $58 \mu \mathrm{L}(0.57 \mathrm{mmol})$ of 2-ethynylpyridine in acetonitrile $(8 \mathrm{~mL})$ with $22.96 \mathrm{mg}(0.115 \mathrm{mmol})$ of $\mathrm{Cu}(\mathrm{OAc})_{2} \cdot \mathrm{H}_{2} \mathrm{O}$ and $45.69 \mathrm{mg}(0.23 \mathrm{mmol})$ of sodium ascorbate yielded the desired compound $\mathbf{2} \mathbf{a}$ as a yellow solid. Suitable crystals of $\mathbf{2} \mathbf{a}$ for $\mathbf{X}$ ray crystal structure determination were grown by slow evaporation of acetonitrile solution.

Yield: $138 \mathrm{mg}(74 \%) ; \mathrm{mp} 198-201{ }^{\circ} \mathrm{C} ;{ }^{1} \mathrm{H}$ NMR (300 MHz, DMSO-d 6 ): $\delta / \mathrm{ppm}=3.34$ $\left(\mathrm{t}, J=7.2 \mathrm{~Hz}, 2 \mathrm{H}, \mathrm{CH}_{2}\right), 4.75\left(\mathrm{t}, J=7.2 \mathrm{~Hz}, 2 \mathrm{H}, \mathrm{NCH}_{2}\right), 7.29\left(\mathrm{~s}, 2 \mathrm{H}, \mathrm{NH}_{2}\right), 7.33(\mathrm{dd}, J=7.4$, $\left.5.2 \mathrm{~Hz}, 1 \mathrm{H}, \mathrm{H}_{\mathrm{pyr}}\right), 7.41\left(\mathrm{~d}, J=8.3 \mathrm{~Hz}, 2 \mathrm{H}, \mathrm{H}_{\mathrm{Ar}}\right), 7.72\left(\mathrm{~d}, J=8.3 \mathrm{~Hz}, 2 \mathrm{H}, \mathrm{H}_{\mathrm{Ar}}\right), 7.88(\mathrm{td}$, $\left.J=7.7,1.7 \mathrm{~Hz}, 1 \mathrm{H}, \mathrm{H}_{\text {pyr }}\right), 8.00\left(\mathrm{~d}, J=8.0 \mathrm{~Hz} 1 \mathrm{H}, \mathrm{H}_{\text {pyr }}\right), 8.58\left(\mathrm{~d}, J=5.0 \mathrm{~Hz}, 1 \mathrm{H}, \mathrm{H}_{\text {pyr }}\right), 8.61$ $\left(\mathrm{s}, 1 \mathrm{H}, \mathrm{H}_{\mathrm{ta}}\right) ;{ }^{13} \mathrm{C}$ NMR $\left(75 \mathrm{MHz}, \mathrm{DMSO}-\mathrm{d}_{6}\right): \delta / \mathrm{ppm}=35.1,50.1\left(\mathrm{CH}_{2}\right), 119.4,123.2,137.2$, 
149.6 $\left(\mathrm{CH}_{\text {pyr }}\right), 123.0\left(\mathrm{CH}_{\mathrm{ta}}\right), 125.7,129.2\left(\mathrm{CH}_{\mathrm{Ar}}\right), 141.8,142.5\left(\mathrm{C}_{\mathrm{Ar}}\right), 147.1\left(\mathrm{C}_{\text {pyr }}\right), 149.9\left(\mathrm{C}_{\mathrm{ta}}\right)$; IR $\left.(\mathrm{KBr}): v\left(\mathrm{NH}_{2}\right)=3139 \mathrm{~cm}^{-1} ; \mathrm{MS} \mathrm{ESI}^{+}\right): \mathrm{m} / z=330.1[\mathrm{M}+\mathrm{H}]^{+}$; HRMS calculated for $\mathrm{C}_{15} \mathrm{H}_{16} \mathrm{~N}_{5} \mathrm{O}_{2} \mathrm{~S}\left([\mathrm{M}+\mathrm{H}]^{+}\right)$330.1025, found 330.1031 .

7-(2-(4-(2-pyridyl)-1H-1,2,3-triazol-1-yl)-ethoxy)-4-methyl-2H-chromen-2-one (2b) $606 \mathrm{mg}(2.47 \mathrm{mmol})$ of $\mathbf{1 b}$ and $0.3 \mathrm{~mL}(2.96 \mathrm{mmol})$ of 2-ethynylpyridine in acetonitrile $(25 \mathrm{~mL})$ with $97.83 \mathrm{mg}(0.49 \mathrm{mmol})$ of $\mathrm{Cu}(\mathrm{OAc})_{2} \cdot \mathrm{H}_{2} \mathrm{O}$ and $194.68 \mathrm{mg}(0.98 \mathrm{mmol})$ of sodium ascorbate yielded the desired compound $\mathbf{2} \mathbf{b}$ as a yellow solid. Suitable crystals of $\mathbf{2} \mathbf{b}$ for $\mathbf{X}$ ray crystal structure determination were grown by slow evaporation of chloroform solution.

Yield: $753 \mathrm{mg}(88 \%)$; mp 193-195 ${ }^{\circ} \mathrm{C} ;{ }^{1} \mathrm{H}$ NMR (300 MHz, DMSO-d 6 ): $\delta / \mathrm{ppm}=2.36$ $\left(\mathrm{d}, J=1.2 \mathrm{~Hz}, 3 \mathrm{H}, \mathrm{CH}_{3}\right), 4.61\left(\mathrm{t}, J=5.0 \mathrm{~Hz}, 2 \mathrm{H}, \mathrm{CH}_{2} \mathrm{~N}\right), 4.89\left(\mathrm{t}, J=5.0 \mathrm{~Hz}, 2 \mathrm{H}, \mathrm{CH}_{2} \mathrm{O}\right)$, $6.20(\mathrm{q}, J=1.2 \mathrm{~Hz}, 1 \mathrm{H}, \mathrm{CH}), 6.94\left(\mathrm{dd}, J=8.8,2.5 \mathrm{~Hz}, 1 \mathrm{H}, \mathrm{CH}_{\mathrm{Ar}}\right), 7.02(\mathrm{~d}, J=2.5 \mathrm{~Hz}, 1 \mathrm{H}$, $\left.\mathrm{CH}_{\mathrm{Ar}}\right), 7.33\left(\mathrm{ddd}, J=7.5,4.9,1.3 \mathrm{~Hz}, 1 \mathrm{H}, \mathrm{CH}_{\mathrm{pyr}}\right), 7.64\left(\mathrm{~d}, J=8.8 \mathrm{~Hz}, 1 \mathrm{H}, \mathrm{CH}_{\mathrm{Ar}}\right), 7.88(\mathrm{td}$, $\left.J=7.7,1.8 \mathrm{~Hz}, 1 \mathrm{H}, \mathrm{CH}_{\mathrm{pyr}}\right), 8.03\left(\mathrm{dt}, J=7.9,1.1 \mathrm{~Hz}, 1 \mathrm{H}, \mathrm{CH}_{\text {pyr }}\right), 8.59(\mathrm{ddd}, J=4.8,1.7,0.9 \mathrm{~Hz}$, $\left.1 \mathrm{H}, \mathrm{CH}_{\mathrm{pyr}}\right), 8.69\left(\mathrm{~s}, 1 \mathrm{H}, \mathrm{CH}_{\mathrm{ta}}\right) ;{ }^{13} \mathrm{C} \mathrm{NMR}\left(75 \mathrm{MHz}, \mathrm{DMSO}-\mathrm{d}_{6}\right): \delta / \mathrm{ppm}=18.1\left(\mathrm{CH}_{3}\right), 49.0$ $\left(\mathrm{CH}_{2} \mathrm{~N}\right), 66.6\left(\mathrm{CH}_{2} \mathrm{O}\right), 101.4,112.5,126.5\left(\mathrm{CH}_{\mathrm{Ar}}\right), 111.4(\mathrm{CH}), 113.5\left(\mathrm{CqCH}_{3}\right), 119.4,123.0$, 137.2, $149.6\left(\mathrm{CH}_{\text {pyr }}\right), 123.7\left(\mathrm{CH}_{\mathrm{ta}}\right), 147.3(\mathrm{Cq} \cdot$ ta $), 149.9$ (Cq.pyr), 153.3, 154.6 (Cq.Ar $), 160.1$ $(\mathrm{Cq}=\mathrm{O}), 160.8$ (Cq.ArO); IR (KBr): $v(\mathrm{CAr}-\mathrm{H})=3071, v(\mathrm{C}=\mathrm{O})=1700,(\mathrm{C}=\mathrm{C})=1611 \mathrm{~cm}^{-1}$; MS(ESI $\left.{ }^{+}\right): m / z=349.13[\mathrm{M}+\mathrm{H}]^{+}$; HRMS calculated for $\mathrm{C}_{19} \mathrm{H}_{17} \mathrm{~N}_{4} \mathrm{O}_{3}\left([\mathrm{M}+\mathrm{H}]^{+}\right) 349.1301$, found 349.1299 .

\subsection{2. $\operatorname{Re}(\mathrm{I})$-Complexes Synthesis}

General Procedure: A solution of $\mathbf{2 a} / \mathbf{2 b}(1$ eq. $)$ and commercial $\left[\operatorname{Re}(\mathrm{CO})_{5} \mathrm{Cl}\right](1.1$ eq. $)$ in methanol was stirred for $12 \mathrm{~h}$ at $65^{\circ} \mathrm{C}$. After cooling to room temperature, the solution was concentrated until $3 \mathrm{~mL}$ and then a precipitate was obtained. $5-8 \mathrm{~mL}$ of methanol was added to the precipitate. The mixture was heated then cooled and stored at $4{ }^{\circ} \mathrm{C}$ for $2 \mathrm{~h}$ before the supernatant was carefully removed. This process was repeated three times before the precipitate was dried under vacuum.

$\left[(\mathbf{2 a}) \operatorname{Re}(\mathrm{CO})_{3} \mathrm{Cl}\right],(\mathbf{3 a})$ :

$70 \mathrm{mg}(0.21 \mathrm{mmol})$ of $2 \mathrm{a}$ and $83.2 \mathrm{mg}(0.23 \mathrm{mmol})$ of $\left[\operatorname{Re}(\mathrm{CO}){ }_{5} \mathrm{Cl}\right]$ in methanol $(8 \mathrm{~mL})$ yielded the desired complex $\mathbf{3} \mathbf{a}$ as a white solid. Suitable crystals of $\mathbf{3 a}$ for X-ray crystal structure determination were grown by slow evaporation of methanol solution.

Yield: $105 \mathrm{mg}(79 \%) ; \mathrm{mp} 249-252{ }^{\circ} \mathrm{C} ;{ }^{1} \mathrm{H}$ NMR (300 MHz, DMSO-d 6 ): $\delta / \mathrm{ppm}=3.39$ $\left(\mathrm{t}, J=7.40 \mathrm{~Hz}, 2 \mathrm{H}, \mathrm{CH}_{2}\right), 4.90\left(\mathrm{t}, J=7.40 \mathrm{~Hz}, 2 \mathrm{H}, \mathrm{NCH}_{2}\right), 7.31\left(\mathrm{~s}, 2 \mathrm{H}, \mathrm{NH}_{2}\right), 7.45(\mathrm{~d}$, $\left.J=8.3 \mathrm{~Hz}, 2 \mathrm{H}, \mathrm{H}_{\mathrm{Ar}}\right), 7.64\left(\mathrm{ddd}, J=6.9,5.5,2.2 \mathrm{~Hz}, 1 \mathrm{H}, \mathrm{H}_{\mathrm{pyr}}\right), 7.74\left(\mathrm{~d}, J=8.3 \mathrm{~Hz}, 2 \mathrm{H}, \mathrm{H}_{\mathrm{Ar}}\right)$ 8.19-8.37 (m, 2H, 2 $\left.\mathrm{H}_{\text {pyr }}\right), 8.97\left(\mathrm{dt}, J=5.6,1.1 \mathrm{~Hz}, 1 \mathrm{H}, \mathrm{H}_{\mathrm{pyr}}\right), 9.22\left(\mathrm{~s}, 1 \mathrm{H}, \mathrm{H}_{\mathrm{ta}}\right) ;{ }^{13} \mathrm{C} \mathrm{NMR}$ $\left(75 \mathrm{MHz}, \mathrm{DMSO}-\mathrm{d}_{6}\right): \delta / \mathrm{ppm}=34.7,52.2\left(\mathrm{CH}_{2}\right), 122.6\left(\mathrm{CH}_{\mathrm{ta}}\right), 125.9,129.4\left(\mathrm{CH}_{\mathrm{Ar}}\right), 126.0$, $126.5,140.7,148.6\left(\mathrm{CH}_{\text {pyr }}\right), 140.9,142.8\left(\mathrm{C}_{\mathrm{Ar}}\right), 148.1\left(\mathrm{C}_{\mathrm{pyr}}\right), 153.1\left(\mathrm{C}_{\mathrm{ta}}\right), 189.5,196.8,197.7$ $(\mathrm{CO}) ; \mathrm{IR}(\mathrm{KBr}): v\left(\mathrm{NH}_{2}\right)=3216, v(\mathrm{CO})=2024,1926,1894 \mathrm{~cm}^{-1} ; \mathrm{MS}\left(\mathrm{ESI}^{+}\right): \mathrm{m} / z=656[\mathrm{M}+$ $\left.\mathrm{Na}]^{+}\right)$; HRMS calculated for $\mathrm{C}_{18} \mathrm{H}_{15} \mathrm{~N}_{5} \mathrm{O}_{5} \mathrm{NaSClRe}\left([\mathrm{M}+\mathrm{Na}]^{+}\right)$655.9910, found 655.9930.

$\left[(2 \mathbf{b}) \operatorname{Re}(\mathrm{CO})_{3} \mathrm{Cl}\right],(3 \mathbf{b})$ :

$350 \mathrm{mg}(1.01 \mathrm{mmol})$ of $\mathbf{2} \mathbf{b}$ and $438 \mathrm{mg}(1.21 \mathrm{mmol})$ of $\left[\mathrm{Re}(\mathrm{CO})_{5} \mathrm{Cl}\right]$ in methanol $(30 \mathrm{~mL})$ yielded the desired complex $\mathbf{3 b}$ as a white solid. Suitable crystals of $\mathbf{3 b}$ for $\mathbf{X}$-ray crystal structure determination were grown by slow evaporation of DMSO solution.

Yield: $581 \mathrm{mg}(88 \%) ; \mathrm{mp} 197-199{ }^{\circ} \mathrm{C} ;{ }^{1} \mathrm{H}$ NMR (300 MHz, DMSO-d 6 ): $\delta / \mathrm{ppm}=2.38$ $\left(\mathrm{d}, J=1.3 \mathrm{~Hz}, 3 \mathrm{H}, \mathrm{CH}_{3}\right), 4.65\left(\mathrm{t}, J=5.0 \mathrm{~Hz}, 2 \mathrm{H}, \mathrm{CH}_{2} \mathrm{~N}\right), 5.11\left(\mathrm{t}, J=5.0 \mathrm{~Hz}, 2 \mathrm{H}, \mathrm{CH}_{2} \mathrm{O}\right)$, $6.22(\mathrm{q}, J=1.2 \mathrm{~Hz}, 1 \mathrm{H}, \mathrm{CH}), 7.01\left(\mathrm{dd}, J=8.8,2.5 \mathrm{~Hz}, 1 \mathrm{H}, \mathrm{CH}_{\mathrm{Ar}}\right), 7.10(\mathrm{~d}, J=2.5 \mathrm{~Hz}, 1 \mathrm{H}$, $\left.\mathrm{CH}_{\mathrm{Ar}}\right), 7.64\left(\mathrm{ddd}, J=7.3,5.6,1.6 \mathrm{~Hz}, 1 \mathrm{H}, \mathrm{CH}_{\mathrm{pyr}}\right), 7.69\left(\mathrm{~d}, J=8.8 \mathrm{~Hz}, 1 \mathrm{H}, \mathrm{CH}_{\mathrm{Ar}}\right), 8.30(\mathrm{td}$, $\left.J=7.7,1.5 \mathrm{~Hz}, 1 \mathrm{H}, \mathrm{CH}_{\text {pyr }}\right), 8.36\left(\mathrm{ddd}, J=8.0,1.6,0.8 \mathrm{~Hz}, 1 \mathrm{H}, \mathrm{CH}_{\text {pyr }}\right), 8.97(\mathrm{dt}, J=5.6,1.2 \mathrm{~Hz}$, $\left.1 \mathrm{H}, \mathrm{CH}_{\mathrm{pyr}}\right), 9.36\left(\mathrm{~s}, 1 \mathrm{H}, \mathrm{CH}_{\mathrm{ta}}\right) ;{ }^{13} \mathrm{C} \mathrm{NMR}\left(75 \mathrm{MHz}, \mathrm{DMSO}-\mathrm{d}_{6}\right): \delta / \mathrm{ppm}=18.1\left(\mathrm{CH}_{3}\right), 51.1$ $\left(\mathrm{CH}_{2} \mathrm{~N}\right), 66.1\left(\mathrm{CH}_{2} \mathrm{O}\right), 101.8,112.4,126.6\left(\mathrm{CH}_{\mathrm{Ar}}\right), 111.5(\mathrm{CH}), 113.7\left(\mathrm{CqCH}_{3}\right), 122.7,126.5$, 140.7, $153.1\left(\mathrm{CH}_{\text {pyr }}\right), 126.5\left(\mathrm{CH}_{\mathrm{ta}}\right), 148.3$ (Cq.ta), 148.6 (Cq.pyr), 153.3, 154.6 (Cq.Ar), 160.0 $(\mathrm{Cq}=\mathrm{O}), 160.6$ (Cq.ArO),189.5, 196.7, $197.6(\mathrm{CO}) ; \mathrm{IR}(\mathrm{KBr}): v\left(\mathrm{C}_{\mathrm{Ar}}-\mathrm{H}\right)=3076, v(\mathrm{CO})=2021$, 
1924, 1899, $\left.v(\mathrm{C}=\mathrm{O})=1716, v(\mathrm{C}=\mathrm{C})=1618 \mathrm{~cm}^{-1} ; \mathrm{MS} \mathrm{ESI}^{+}\right): m / z=675[\mathrm{M}+\mathrm{Na}]^{+} ; \mathrm{HRMS}$ calculated for $\mathrm{C}_{22} \mathrm{H}_{16} \mathrm{~N}_{4} \mathrm{O}_{6} \mathrm{ClRe}\left([\mathrm{M}+\mathrm{H}]^{+}\right)$652.0288, found 652.0288 .

\subsection{Crystal Structure Determination}

X-ray intensity data of ligands $\mathbf{2 a}, \mathbf{2} \mathbf{b}$ and corresponding rhenium complexes $3 \mathrm{a}, 3 \mathbf{b}$ were collected on a Bruker D8 VENTURE diffractometer (Karlsruhe, Germany), and using graphite mono-chromated Mo K $\alpha$ radiation $(\lambda=0.71073 \AA)$ for $\mathbf{2} \mathbf{b}, \mathbf{3 a}$ and $\mathbf{3} \mathbf{b}$, and $\mathrm{Cu}$ $\mathrm{K} \alpha$ radiation $(\lambda=1.54178 \AA)$ for $2 \mathbf{a}$ at $193 \mathrm{~K}$. The semi-empirical absorption corrections were employed [SADABS, Program for data correction, Bruker-AXS]. Crystallographic data and refinement details are given in Table 1. The structures were solved using an intrinsic phasing method [35], and refined by full matrix least squares procedures on F2 [36]. All non- $\mathrm{H}$ atoms were refined with anisotropic displacement parameters. Hydrogen atoms were refined isotropically at calculated positions, using a riding model with their isotropic displacement parameters constrained to equal 1.5 times the equivalent isotropic displacement parameters of their pivot atoms for terminal sp3 carbon, and 1.2 times for all other carbon atoms. H atoms on N (2a and 3a) were located by difference Fourier maps and freely refined. In complexes $\mathbf{3 a}$ and $\mathbf{3 b}$ some parts of the molecules were disordered. Several restraints (SAME, SIMU, DELU) were applied to refine some moieties of the molecules and to avoid the collapse of the structures during the least-squares refinement by the large anisotropic displacement parameters.

Table 1. Crystal data and structure refinement for $\mathbf{2 a}, \mathbf{2 b}, \mathbf{3 a}$ and $3 \mathbf{b}$.

\begin{tabular}{|c|c|c|c|c|}
\hline & $2 a$ & $2 b$ & [(2a) $\left.\mathrm{ReCO}_{3} \mathrm{Cl}\right],(3 \mathrm{a})$ & {$\left[(2 \mathrm{~b}) \mathrm{ReCO}_{3} \mathrm{Cl}\right] . \mathrm{DMSO},(3 \mathrm{~b})$} \\
\hline Empirical formula & $\mathrm{C}_{15} \mathrm{H}_{15} \mathrm{~N}_{5} \mathrm{O}_{2} \mathrm{~S}$ & $\mathrm{C}_{19} \mathrm{H}_{16} \mathrm{~N}_{4} \mathrm{O}_{3}$ & $\mathrm{C}_{18} \mathrm{H}_{15} \mathrm{Cl} \mathrm{N}_{5} \mathrm{O}_{5} \operatorname{ReS}$ & $\begin{array}{c}\mathrm{C}_{22} \mathrm{H}_{16} \mathrm{Cl} \mathrm{N}_{4} \mathrm{O}_{6} \mathrm{Re}, \\
\mathrm{C}_{2} \mathrm{H}_{6} \mathrm{OS}\end{array}$ \\
\hline Formula weight & 329.38 & 348.36 & 635.06 & 732.16 \\
\hline $\mathrm{T}[\mathrm{K}]$ & 193(2) & 193(2) & 193(2) & 193(2) \\
\hline Wavelength [Å] & 1.54178 & 0.71073 & 0.71073 & 0.71073 \\
\hline Crystal system & Orthorhombic & Monoclinic & Monoclinic & Triclinic \\
\hline \multirow{7}{*}{ Unit cell dimensions $\left[\AA^{\circ},{ }^{\circ}\right]$} & Pbca & $P 2_{1} / \mathrm{c}$ & $P 2_{1} / \mathrm{c}$ & $P 1$ \\
\hline & $\mathrm{a}=18.2308(4)$ & $\mathrm{a}=12.6468(4)$ & $\mathrm{a}=8.0178(3)$ & $\mathrm{a}=8.0868(3)$ \\
\hline & $\mathrm{b}=9.3614(2)$ & $\mathrm{b}=12.2772(4)$ & $\mathrm{b}=33.4017(15)$ & $\mathrm{b}=8.6809(3)$ \\
\hline & $c=35.5572(7)$ & $c=10.5793(4)$ & $\mathrm{c}=7.9521(3)$ & $c=19.6106(7)$ \\
\hline & $\alpha=90$ & $\alpha=90$ & $\alpha=90$ & $\alpha=78.5276(11)$ \\
\hline & $\beta=90$ & $\beta=90.4488(12)$ & $\beta=90.9698(14)$ & $\beta=79.9489(11)$ \\
\hline & $\gamma=90$ & $\gamma=90$ & $\gamma=90$ & $\gamma=84.7728(12)$ \\
\hline $\mathrm{V}\left[\AA^{3}\right]$ & $6068.4(2)$ & $1642.57(10)$ & $2129.33(15)$ & $1326.20(8)$ \\
\hline $\mathrm{Z}$ & 16 & 4 & 4 & 2 \\
\hline$\rho_{\text {calcd }}\left[\mathrm{Mg} / \mathrm{m}^{3}\right]$ & 1.442 & 1.409 & 1.981 & 1.833 \\
\hline$\mu\left[\mathrm{mm}^{-1}\right]$ & 2.057 & 0.098 & 5.971 & 4.812 \\
\hline Max. and min. transm. & 0.7526 and 0.6330 & 0.7466 and 0.7182 & 0.7457 and 0.5868 & 0.7461 and 0.5778 \\
\hline $\mathrm{F}(000)$ & 2752 & 728 & 1224 & 716 \\
\hline Crystal size $\left[\mathrm{mm}^{3}\right]$ & $0.200 \times 0.160 \times 0.100$ & $0.520 \times 0.240 \times 0.200$ & $0.200 \times 0.060 \times 0.020$ & $0.300 \times 0.250 \times 0.220$ \\
\hline \multirow[t]{2}{*}{$\theta$ range $\left[{ }^{\circ}\right]$} & 2.485 to 65.059 & 3.001 to 33.415 & 2.837 to 28.410 & 3.068 to 30.660 \\
\hline & $-21 \leq \mathrm{h} \leq 13$ & $-19 \leq \mathrm{h} \leq 18$ & $-10 \leq \mathrm{h} \leq 10$ & $-11 \leq \mathrm{h} \leq 11$ \\
\hline \multirow[t]{2}{*}{ Limiting indices } & $-11 \leq \mathrm{k} \leq 10$ & $-18 \leq \mathrm{k} \leq 18$ & $-44 \leq \mathrm{k} \leq 44$ & $-12 \leq \mathrm{k} \leq 12$ \\
\hline & $-41 \leq 1 \leq 40$ & $-16 \leq 1 \leq 12$ & $-10 \leq 1 \leq 9$ & $-28 \leq 1 \leq 25$ \\
\hline Reflections collected & 39,890 & 50,858 & 67,707 & 63,681 \\
\hline Unique reflections $\left(R_{\text {int }}\right)$ & $5129[0.0691]$ & $5995[0.0270]$ & $5322[0.0418]$ & 8128 [0.0193] \\
\hline \multicolumn{5}{|l|}{$\begin{array}{c}\text { Completeness to } 2 \theta=65.059^{\circ} \\
\text { for } 2 a\end{array}$} \\
\hline$=25.242^{\circ}$ for $\mathbf{2 b}$ & $99.4 \%$ & $99.5 \%$ & $99.8 \%$ & $99.4 \%$ \\
\hline \multirow{2}{*}{\multicolumn{5}{|c|}{$\begin{array}{l}=25.242^{\circ} \text { for } 3 a \\
=25.242^{\circ} \text { for } 3 b\end{array}$}} \\
\hline & & & & \\
\hline Data/restraints/parameters & $5129 / 0 / 431$ & $5995 / 0 / 236$ & $5322 / 43 / 305$ & $8128 / 108 / 381$ \\
\hline Goodness-of-fit (GOF) on $\mathrm{F}^{2}$ & 1.044 & 1.027 & 1.245 & 1.137 \\
\hline Final $R$ indices $[I>2 \sigma(I)]$ & $\mathrm{R}_{1}=0.0465$ & $\mathrm{R}_{1}=0.0455$ & $\mathrm{R}_{1}=0.0317$ & $\mathrm{R}_{1}=0.0160$ \\
\hline & $\begin{array}{c}w_{2}=0.0859 \\
R_{1}=0.0790\end{array}$ & $\begin{array}{c}w R_{2}=0.1138 \\
R_{1}=0.0626\end{array}$ & $\begin{array}{c}w R_{2}=0.0524 \\
R_{1}=0.0404\end{array}$ & $\begin{array}{c}w K_{2}=0.0374 \\
R_{1}=0.0176\end{array}$ \\
\hline$R$ indices (all data) & $\mathrm{wR}_{2}=0.0957$ & $\mathrm{wR}_{2}=0.1246$ & $\mathrm{wR}_{2}=0.0542$ & $\mathrm{wR}_{2}=0.0380$ \\
\hline $\begin{array}{l}\text { Largest difference in peak and } \\
\text { hole }\left[\mathrm{e} \AA^{-3}\right]\end{array}$ & 0.234 and -0.357 & 0.356 and -0.268 & 0.762 and -1.968 & 1.040 and -0.881 \\
\hline
\end{tabular}


The supplementary crystallographic data for this paper for compounds 2a (CCDC 2098097), 2b (CCDC 2098098), 3a (CCDC 2098099 ) and 3b (CCDC 2098100 ) can be obtained free of charge from CCDC.

\subsection{Carbonic Anhydrase Inhibition Assays}

An Applied Photophysics stopped-flow instrument was used for assaying the CA catalyzed $\mathrm{CO}_{2}$ hydration activity. Phenol red (at a concentration of $0.2 \mathrm{mM}$ ) was used as indicator, working at the absorbance maximum of $557 \mathrm{~nm}$, with $20 \mathrm{mM}$ Hepes (pH 7.5) as buffer, and $20 \mathrm{mM} \mathrm{Na}_{2} \mathrm{SO}_{4}$ (for maintaining the constant ionic strength), following the initial rates of the $\mathrm{CA}$-catalyzed $\mathrm{CO}_{2}$ hydration reaction for a period of 10-100 s. The $\mathrm{CO}_{2}$ concentrations ranged from 1.7-17 $\mathrm{mM}$ for the determination of the kinetic parameters and inhibition constants. In particular, $\mathrm{CO}_{2}$ was bubbled in distilled deionized water for $30 \mathrm{~min}$ so that the water was saturated (the concentration at a specific temperature is known from literature). In addition, a $\mathrm{CO}_{2}$ assay kit (from Sigma) was used to measure the concentration in variously diluted solutions obtained from the saturated solution (which was kept at the same temperature and a constant bubbling during the experiments). For each inhibitor, at least six traces of the initial $5-10 \%$ of the reaction were used for determining the initial velocity [37]. The uncatalyzed rates were determined in the same manner and subtracted from the total observed rates. Stock solutions of inhibitor $(0.1 \mathrm{mM})$ were prepared in distilled-deionized water and dilutions up to $0.01 \mathrm{nM}$ were completed thereafter with distilled-deionised water. Inhibitor and enzyme solutions were pre-incubated together for $15 \mathrm{~min}-2 \mathrm{~h}$ (or longer, i.e., $4-6 \mathrm{~h}$ ) at room temperature (at $4{ }^{\circ} \mathrm{C}$ for the incubation periods longer than $15 \mathrm{~min}$ ) prior to assay, to allow for the formation of the E-I complex. The inhibition constants were obtained by non-linear least-squares methods using PRISM 3 and the Cheng-Prusoff equation [38,39], as reported earlier, and represent the mean from at least three different determinations. hCA I was purchased by Sigma-Aldrich and used without further purification, whereas all the other hCA isoforms were recombinant ones obtained in-house as reported earlier $[40,41]$.

\subsection{Molecular Docking Studies}

There are five known mechanisms of carbonic anhydrase inhibition [42]. Two of these are considered to be inhibitors that (i) coordinate directly with the zinc ion in the CA active site and (ii) block the entrance to the active site [42]. The former classes are the classical inhibitors, such as sulfonamides and their isosteres, and some of them are co-crystallized with hCA IX. The latter (CAIs), such as coumarin derivatives, are known to bind to the CA cavity in a different region than the sulfonamide class [30-32]. Therefore, the 3D crystal structures of the proteins used in molecular docking were extracted from the RCSB Protein Data Bank web server. The X-ray crystal structure of hCA-IX complexed with 5-(1-naphthalen-1-yl-1,2,3-triazol-4-yl)thiophene-2-sulfonamide (PDB: 5FL4, Ligand ID: 9FK, 1.82A) [43] was used to predict the binding mode interactions of the synthesized sulfonamide compounds. Similarly, two other PDB crystal structures were downloaded and used to predict the binding mode of our synthesized coumarin-containing compounds (3F8E [30] and 5DVX [44] for hCA II and IX, respectively).

The downloaded crystal structures were prepared using the Discovery Studio visualization code [45]. A single chain was retained if there were multiple protein chains, and all other small non-protein molecules were removed from the crystal structures. To correctly estimate the interaction mode of the native coumarin, co-crystallized in hCA II, and thus the coumarin compounds synthesized against isoform IX, the prepared structure of hCA IX (pdb: 5DVX) was overlaid on the prepared structure of hCA II-coumarin (pdb: 3F8E). Next, the co-crystallized ligand (2-amino-2-hydroxymethyl-propene-1,3-diol) inside the hCA IX isoform was removed, and the hydrolyzed coumarin of the hCA II isoform, together with its $\mathrm{Zn}^{2+}$-coordinated water molecule, was inserted inside the prepared structure of the hCA IX isoform. The alignment of the protein structures was performed by the Chimera code [46] 
and is visualized in Figure S1 in the Supplementary Information. These enzyme-inhibitor complexes were taken as initial structures for docking studies using AutoDock4.2 software.

The AutoDock program has the ability to take into account the flexibility of docked inhibitors during the docking process. To explore the binding modes of the protein with the inhibitors, the Lamarckian genetic algorithm (LGA) [47] was run. Using the AutoDock tools [48], the partial charges of the Kollman unit atom and the essential $\mathrm{H}$ atoms were added. Gasteiger partial charges were added to the ligand atoms. The non-polar hydrogen atoms were merged. Interestingly, a charge of +2 was assigned to the $\mathrm{Zn}$ atom which is attached by three histidine residues. All proteins were kept rigid and all rotational torsional bonds of the ligands were left free to allow flexible docking. The docking area was selected by constructing a grid box of size $40 \times 40 \times 40 \AA$ points centered on the $x, y$ and $z$ coordinates of $14.09,-27.414$ and 59.605 for sulfonamide-based compounds, and $-5.095,6.414$ and 9.427 for coumarin-based compounds, respectively, with a grid spacing of $0.375 \AA$, using the AutoGrid program [48]. In addition, to predict atom-specific affinity maps, electrostatic, and desolvation potential maps, a distance-dependent dielectric function was assigned. Docking calculations were performed with the Lamarckian genetic algorithm LGA. 500 docking trials were defined as conformational searches and the root mean square (RMS) cluster tolerance was set at $2.0 \AA$. All other parameters were kept at their default settings [48].

To validate the docking protocol detailed above, we docked native inhibitors [5-(1naphthalen-1-yl-1,2,3-triazol-4-yl)thiophene-2-sulfonamide and 2-amino-2-hydroxymethylpropene-1,3-diol] of hCA isoforms. The positions and orientations occupied by the native ligands were compared to the conformations found in the X-ray structures available in the Protein Data Bank. The root mean square deviation (RMSD) between the experimental structure and the docked structure, and the docked free energy values returned by AutoDock were computed to assess the accuracy of the calculated poses.

In the case of our compounds (the organic ligands $\mathbf{2} \mathbf{a} / \mathbf{2} \mathbf{b}$ and their corresponding rhenium(I) complexes $3 \mathbf{a} / \mathbf{3 b}$ ), the validated method was used to predict their binding conformation in the same regions of the hCA IX cavity occupied by the two co-crystallized ligands. The initial geometries of the synthesized compounds were taken from the $\mathrm{X}$ ray structures and were optimized by the DFT method to minimize energy using the GAUSSIAN-09 program [49]. In the case of the two rhenium compounds, DFT methods were used to give correct results for transition metal-containing systems [50]. Among the different density function methods, the hybrid B3LYP [51,52] proves to be a suitable choice for $f a c-\operatorname{Re}(\mathrm{CO})_{3}$ complexes specifically. Furthermore, the visualization program Gauss View [53], included in GAUSSIAN-09, considers the coordination of the rhenium ring to two nitrogen atoms of the pyta chelating unit as rigid bonds. The Re and $\mathrm{Cl}$ atoms were assigned a charge of +1 and -1 , respectively, the sulfonamide group was constructed in its negative charge $\left(-\mathrm{SO}_{2}-\mathrm{NH}^{-}\right)$and the coumarin unit was constructed in the hydrolyzed and native forms.

\section{Results and Discussion}

\subsection{Chemistry and Structural Characterizations}

Over the last decade, several research groups, including ours, demonstrated that 2-pyridyl-1,2,3-triazole derivatives, known as the pyta ligand, act as efficient chelators for the $\left\{\mathrm{M}(\mathrm{CO})_{3}{ }^{+}\right\}$core $\left(\mathrm{M}={ }^{99 \mathrm{~m}} \mathrm{Tc}\right.$ and $\left.\mathrm{Re}\right)$ [54-63]. In particular, these pyta ligands are interesting tools for the preparation of SPECT radiopharmaceuticals $\left({ }^{99 \mathrm{~m}} \mathrm{Tc}\right)$, luminescent probes $(\mathrm{Re})$ or bimodal imaging agents $\left({ }^{99 \mathrm{~m}} \mathrm{Tc} / \mathrm{Re}\right)$. Numerous monofunctionalized pyta derivatives have been easily prepared by a Copper-catalyzed Alkyne-Azide Cycloaddition reaction $(\mathrm{CuAAC})$. The mild reaction conditions associated with the click approach allowed the preparation of a large number of mono-functionalized pyta derivatives in which 1,4-disubstituted 1,2,3-triazoles form an integral part of the metal chelating system (so called "click-to-chelate" concept) $[64,65]$. We were the first group to use this "click-tochelate" concept to develop tricarbonyl rhenium(I) complexes as carbonic anhydrase IX 
inhibitors [24]. It should be noted that while numerous 1,2,3-triazole-based CA inhibitors have been reported, the triazole ring (formed by the $\mathrm{CuAAC}$ reaction) only acts as a connector between the pharmacophore (coumarin/sulfonamide derivatives) and a metal complex or an organic moiety [66-73].

The synthesis of the targeted compounds $\mathbf{3 a} / \mathbf{3 b}$ is depicted in Scheme 1 . The synthetic strategy adopted is similar to that developed recently by our group [24]. It consists of a three-step procedure. Firstly, two azido compounds $\mathbf{1 a}$ and $\mathbf{1} \mathbf{b}$ were synthesized from the commercial compounds 4-(2-aminoethyl)-benzenesulfonamide and 7-hydroxy-4methylumbelliferone, respectively, according to literature procedures $[33,34]$. These azido intermediates $\mathbf{1 a} \mathbf{a} \mathbf{1}$ bere combined with commercial 2-ethynylpyridine via Copper(I)catalyzed Alkyne-Azide Cycloaddition reaction to get click derivatives containing sulfonamide/coumarin moieties ( $2 \mathbf{a}$ and $\mathbf{2} \mathbf{b}$ ). After purification, the pyta ligands $\mathbf{2} \mathbf{a} / \mathbf{2} \mathbf{b}$ were obtained in good yield (average yield of $81 \%$ ). Both organic pyta compounds were then reacted with a slight excess of rhenium pentacarbonyl chloride in methanol at $65{ }^{\circ} \mathrm{C}$ over $12 \mathrm{~h}$ to give the two tricarbonyl rhenium complexes $3 \mathrm{a} / 3 \mathrm{~b}$ in good yields (c.a. $83 \%$ ).

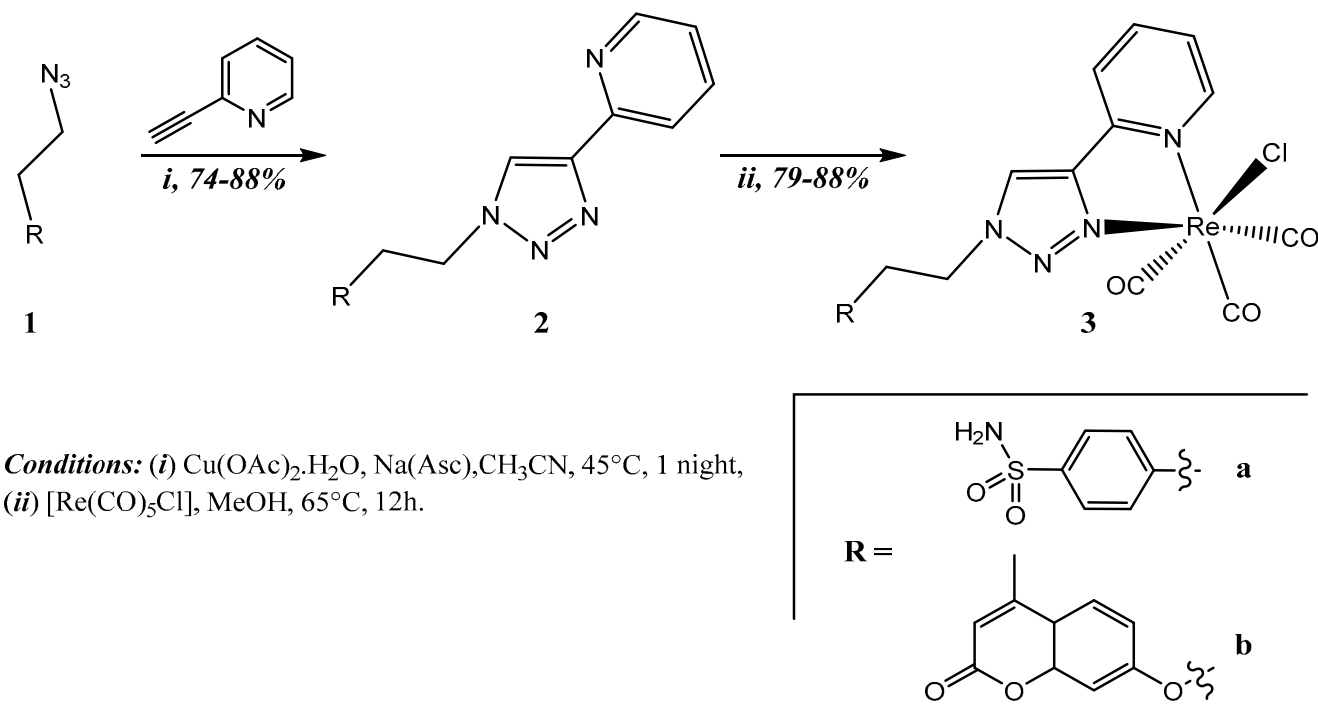

Scheme 1. General synthetic scheme of compounds $\mathbf{2 a}, \mathbf{2} \mathbf{b}$ and $\mathbf{3 a}, \mathbf{3 b}$.

The synthesized compounds (ligands and complexes) are stable in air, either as a solid or in solution, as expected. They were fully characterized by ${ }^{1} \mathrm{H} N \mathrm{NM},{ }^{13} \mathrm{C} \mathrm{NMR}, \mathrm{IR}$ and MS as well as single-crystal X-ray diffraction. Selected parameters of the crystal structures are listed in Table 1, and selected bond lengths and angles values can be found in the Supplementary Data (Supplementary Information, Tables S1 and S2). Our four pyta-based compounds showed classic spectral features (experimental section and/or Supplementary Information for more detail). Briefly, both mono-functionalized pyridyl-1,2,3-triazole derivatives $\mathbf{2} \mathbf{a} / \mathbf{2} \mathbf{b}$ were crystallized in the orthorhombic and monoclinic system groups and their crystals were solved in space groups $P$ bca and $P 2{ }_{1} / c$, respectively (Figure S2 in Supplementary Information for the molecular views of $\mathbf{2 a}$ and $\mathbf{2 b}$ ). Structural features are very similar and compare well to those observed for related complexes, i.e., an anti arrangement adopted by the N1 and N2 atoms (2a), or the N3 and N4 atoms (2b) of the pyridine and triazole rings, respectively, and an azo character of the 1,2,3-triazole ring [24,54-63]. Additionally, a significant contribution to crystal cohesion is provided by a network of intra-layer hydrogen bonds and $\pi-\pi$ intermolecular hydrogen interactions for 2a (Table S3 in Supplementary Information).

According to the Infra-Red spectra of the two rhenium complexes $\mathbf{3 a}$ and $\mathbf{3 b} \mathbf{b}$, the facial arrangement of the $\mathrm{CO}$ ligands in the complexes is confirmed by the pattern of the $\mathrm{CO}$ stretching frequencies, i.e., one sharp, intense absorption $\left(2024 \mathrm{~cm}^{-1}\right.$ for $3 a$ and $2021 \mathrm{~cm}^{-1}$ for $3 \mathbf{b}$ ) and a second broad, intense band in the $1894-1925 \mathrm{~cm}^{-1}$ region [74-76]. The average 
value of the CO stretching frequencies of $1948 \mathrm{~cm}^{-1}$ is consistent with those reported for other pyta ligands and indicates an overall donor strength similar to bipyridine ligands, as expected [74]. In the mass spectra, the prominent peak observed at $m / z 656$ for $3 \mathbf{a}$ and $\mathrm{m} / \mathrm{z}$ 652 for $3 b$ is assigned to [M+ Na] ${ }^{+}$on the basis of the isotopic distribution of ${ }^{185 / 187} \mathrm{Re}$. In the ${ }^{1} \mathrm{H}$ NMR spectra, the triazole proton signals were strongly downfield shifted compared to the spectra of the pyta ligands ( $0.61 \mathrm{ppm}$ for $\mathbf{3 a}$ vs. $\mathbf{2} \mathbf{a}$ and $0.67 \mathrm{ppm}$ for $\mathbf{3} \mathbf{b}$ vs. $\mathbf{2} \mathbf{b}$ ) Additionally, these spectroscopic assignments were confirmed by the solid-state structure of $3 \mathbf{a} / \mathbf{3 b}$ performed by $X$-ray crystallography (as mentioned previously, the selected parameters of the crystal structures are listed in Table 1, and selected bond lengths and angles values can be found in the Supplementary Information, Table S2). As is commonly found for tricarbonyl rhenium(I) complexes, both rhenium(I) centres present a distorted octahedral geometry, as highlighted in Figure 1 [54-63,74]. In the ' $\mathrm{ReC}_{3} \mathrm{~N}_{2} \mathrm{Cl}^{\prime}$ coordination sphere, the three carbon monoxide moieties are facially disposed to maximize Re-CO backbonding. The chelate ring is satisfactorily planar, with unexceptional bond lengths and bond angles close to those observed in similar complexes $\left[\operatorname{Re}(\mathrm{CO})_{3} \mathrm{Cl}\right.$ (pyta derivative)] (the N1-C8-C9-N2 dihedral angles are $0.8(5)^{\circ}$ for $3 \mathbf{a}$ and $2.0(2)^{\circ}$ for $\left.3 \mathbf{b}\right)$. The crystal-packing analysis proved that the molecular structures of both complexes $3 \mathbf{a} / 3 \mathbf{b}$ are stabilized through a network of non-covalent interactions. A network of intermolecular hydrogen interactions was observed between the sulfonamide group and the rhenium core of the adjacent molecule for $3 \mathbf{a}$, while more interactions were detected for the second complex $\mathbf{3 b}$ involving, in particular, the lattice DMSO molecules (Table S3 in Supplementary Information).

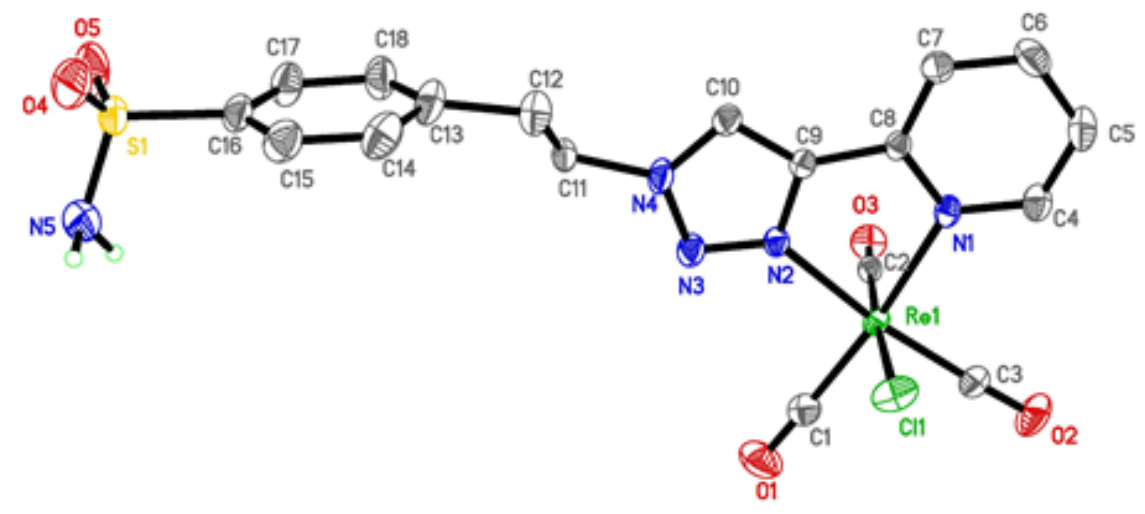

(a)

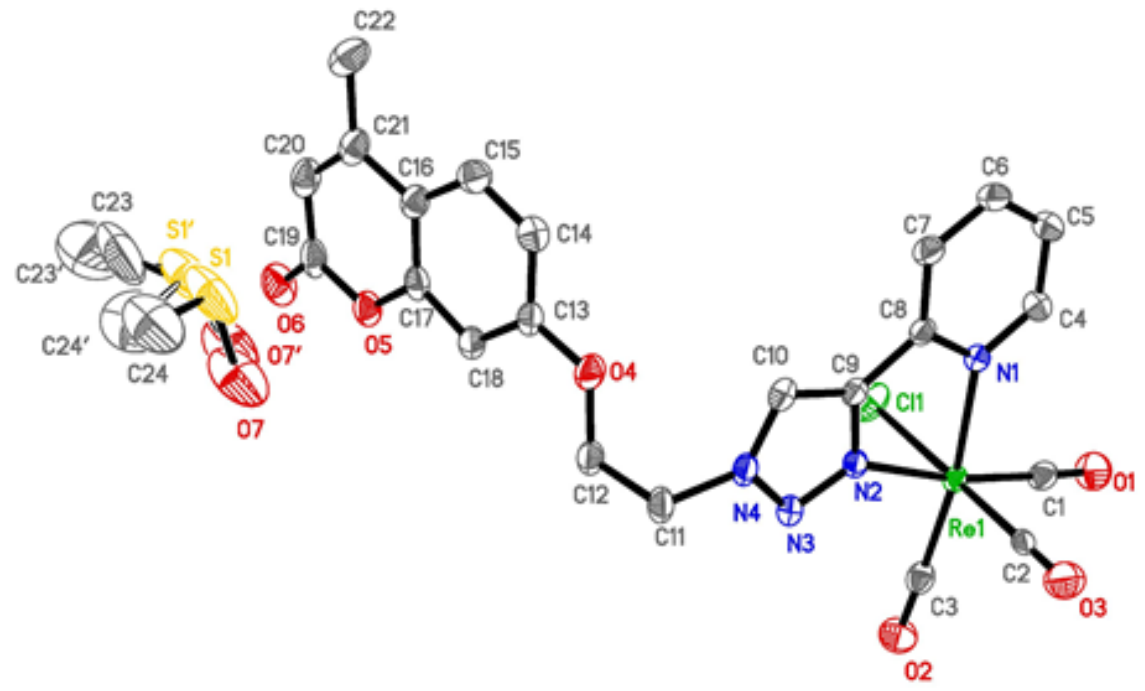

(b)

Figure 1. Molecular views of $\mathbf{3 a}(\mathbf{a})$ and $\mathbf{3 b}(\mathbf{b})$ with $50 \%$ ellipsoidal probability; hydrogen atoms have been omitted for clarity, except $\mathrm{H}$ on N5 atom (3a). 


\subsection{CA Inhibition Assays}

Five compounds, azido intermediate $\mathbf{1} \mathbf{b}$, both ligands $\mathbf{2} \mathbf{a}$ and $\mathbf{2} \mathbf{b}$, and rhenium complexes $\mathbf{3} \mathbf{a}$ and $\mathbf{3} \mathbf{b}$ were tested in vitro for their inhibitory activity against the physiologically relevant hCA isoforms I, II, IX and XII by means of the stopped-flow carbon dioxide hydration assay. Their activities were compared to the standard CAI acetazolamide (AAZ) (Table 2). All compounds reported here were very efficient as hCA IX and XII inhibitors in the nanomolar range (except for compound $\mathbf{1 b}$ with a $K_{\mathrm{i}}$ of $227 \mathrm{nM}$ for hCA IX) with $\mathrm{Ki}$ values close to those of the reference AAZ.

Table 2. Inhibition data of human CA isoforms hCA I, II, IX and XII with the compounds, and the standard CA inhibitor acetazolamide (AAZ) by a stopped flow $\mathrm{CO}_{2}$ hydrase assay.

\begin{tabular}{ccccccccc}
\hline \multicolumn{4}{c}{$\boldsymbol{K}_{\boldsymbol{i}}(\mathbf{n M})^{(\mathbf{a})}$} & \multicolumn{4}{c}{ Selectivity Ratio } \\
\hline & hCA I & hCA II & hCA IX & hCA XII & I/IX & II/IX & I/XII & II/XII \\
\hline $\mathbf{1 b}$ & $>10,000$ & $>10,000$ & 227.6 & 94.9 & $>44$ & $>44$ & $>105$ & $>105$ \\
$\mathbf{2 a}$ & 103.5 & 6.8 & 11.7 & 9.8 & 09 & 0.60 & 10 & 0.70 \\
$\mathbf{2 b}$ & $>10,000$ & $>10,000$ & 44.5 & 12.7 & $>225$ & $>225$ & $>787$ & $>787$ \\
$\mathbf{3 a}$ & 864.2 & 89.7 & 29.7 & 45.5 & 29 & 3 & 19 & 02 \\
$\mathbf{3 b}$ & $>10,000$ & $>10,000$ & 34.9 & 31.7 & $>287$ & $>287$ & $>315$ & $>315$ \\
$\mathbf{A A Z}$ & 250 & 12 & 25 & 5.7 & 10 & 0.50 & 44 & $>2$ \\
\hline
\end{tabular}

(a) mean from 3 different assays, by a stopped-flow technique (errors in the range of $\pm 5-10 \%$ of the reported value). Italic values are the references values of AAZ (acetazolamide).

Among the sulfonamides derivatives, 2a presented the highest hCA IX and XII inhibitory activities, with $K_{\mathrm{i}}$ of 11.7 and $9.8 \mathrm{nM}$, for hCA IX and hCA XII, respectively. Additionally, 2a strongly inhibited the cytosolic isoform hCA II with $K_{\mathrm{i}}$ of $6.8 \mathrm{nM}$, while the inhibition of the cytosolic isoform hCA I was in the sub micromolar range $\left(K_{\mathrm{i}}\right.$ of $\left.103.5 \mathrm{nM}\right)$. The corresponding rhenium complex 3a showed a similar behaviour to $2 \mathbf{a}$. By comparing these results with those obtained previously [24], several structure-activity properties can be established for compounds bearing an arylsulfonamide moiety. Firstly, a better inhibition profile is observed with ligands compared to their corresponding tricarbonyl rhenium analogues. In this study, 2a showed a 2.5- and 4.6-fold higher affinity against hCA IX and hCA XII, respectively, than its rhenium complex $3 \mathbf{a},\left(K_{\mathrm{i}}(\mathbf{2 a})=11.7\right.$ and $9.8 \mathrm{nM}$ vs. $K_{\mathrm{i}}(3 \mathrm{a})=29.7$ and $\left.45.5 \mathrm{nM}\right)$. In contrast, the presence of a metal centre increased selectivity against hCA IX and hCA XII compared to the off-target isoforms hCA I and hCA II. From Table 2, 3a exhibited hCA I/hCA IX and hCA I/hCA XII ratios of 29 and 19, respectively, compared to 9 and 10 for 2a. On the other hand, there is no clear linear relationship between the linker length (between the chelate part and the sulfonamide unit) and the inhibitory activity. While the introduction of a methylene group between the metal part and the sulfonamide unit had a slight negative effect on the inhibition values [24], a linker with an ethylene group increased the inhibitory activity. Thus, for hCA II, $K_{\mathrm{i}}$ values are $4.6 \mathrm{nM}$ (no linker, see ref. [24]), $56.1 \mathrm{nM}$ (one $-\mathrm{CH}_{2}$ - group, see ref. [24]) and $6.8 \mathrm{nM}\left(-\mathrm{CH}_{2} \mathrm{CH}_{2}\right.$ - group, compound $\mathbf{2 a}$, Table 2). Similar behaviour has been reported recently for compounds with linkers with longer carbon chains, and has been explained in particular by a slight intra-molecular movement ability [75].

The tumour-associated isoforms hCA IX and hCA XII were selectively inhibited by all the coumarin derivatives, with inhibition constants ranging from $12.7 \mathrm{nM}$ to $44.5 \mathrm{nM}$, while the hCA I and II isoforms were slightly inhibited (in the micromolar range), as expected. Additionally, the presence of the chelate unit had a positive effect on hCA IX and hCA XII inhibitions. $\mathbf{2 b}$ showed a 5- to 7-fold higher affinity against hCA IX and hCA XII, respectively, than the azido intermediate $\mathbf{1 b},\left(K_{\mathrm{i}}(\mathbf{2 b})=44.5 \mathrm{nM}\right.$ and $12.7 \mathrm{nM}$ vs. $K_{\mathrm{i}}(\mathbf{1 b})=227.6 \mathrm{nM}$ and $94.9 \mathrm{nM})$. The same trend was observed for rhenium complex $\mathbf{3 b}$ compared to $\mathbf{1 b}$.

All of the non-metalated free ligands analyzed here showed better affinity for hCA isoforms I, II, IX and XII than their corresponding rhenium complexes, with the exception of complex $3 \mathbf{b}$, whose inhibitory activity against hCA IX was very slightly superior to that of ligand $\mathbf{2 b}\left(K_{\mathrm{i}}(3 \mathbf{b})=34.9 \mathrm{nM}\right.$ vs. $\left.K_{\mathrm{i}}(\mathbf{2} \mathbf{b})=44.5 \mathrm{nM}\right)$. Despite this slight decrease 
in affinity, rhenium derivatives seem more interesting because of their potential use as imaging agents (with technetium-99m analogues) for the in vivo detection of hCA IX- and hCA XII-expressing tumours in patients. Moreover, among the rhenium (or technetium$99 \mathrm{~m}$ ) complex-based CA inhibitors [23,76], coumarin derivative $\mathbf{3 b}$ showed one of the highest selectivities against hCA IX and hCA XII compared to the off-target isoforms hCA I and hCA II, making it a promising anti-cancer drug candidate (hCA I or hCA II/hCA IX and hCA I or hCA II/hCA XII ratios of 287 and 315 respectively).

\subsection{Molecular Docking Studies}

Molecular docking calculations were performed to predict and understand the binding modes of the synthesized inhibitors $2 / 3$ to the hCA IX active site cavity. Since all synthesized compounds do not contain a sulfonamide moiety, we assumed that in addition to the direct interactions between the ligand and the zinc ion, the studied ligands could also interact with the pocket entrance of the enzyme away from the zinc ion. As previously reported by Maresca et al. [30-32], coumarin derivatives could hydrolyze to form 2-hydroxy-cinnamic acid derivatives, i.e., two possibilities could be found for each molecule, the closed or open coumarin form. In our calculations, we considered this possibility by distinguishing $\mathbf{2 b}$ and $\mathbf{3 b}$ in their non-hydrolyzed forms (Figure 2, compounds $\mathbf{1 P - 2} \mathbf{b}$ and $\mathbf{1 P - 3} \mathbf{b}$ ) from their hydrolyzed forms (Figure 2, compounds $\mathbf{2 P - 2 b}$ and $\mathbf{2 P - 3 b}$ ). To this end, the 5FL4 [43] and 5DVX [44] pdb codes were proposed as hCA IX adduct models for docking studies of synthesized sulfonamide ( $2 \mathbf{a} / \mathbf{3 a})$ and coumarin $(\mathbf{2} \mathbf{b} / \mathbf{3 b})$ compounds, respectively. Using molecular docking processes with AutoDock software, 500 conformations were clustered for each case, while the preferred conformations were selected by examining the cluster with the lowest mean binding energy, the RMSD value between the X-ray and the docked structure, coordination, hydrogen bond interactions and hydrophobic contacts.

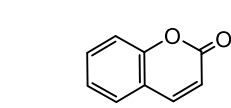

$1 \mathrm{~A}$<smiles></smiles>

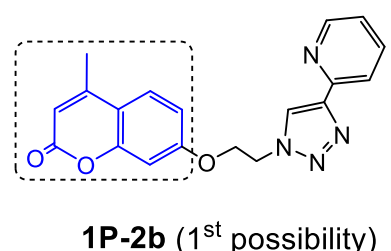

1P-2b ( $1^{\text {st }}$ possibility)

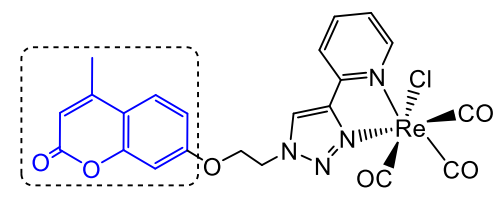

1P-3b $\left(1^{\text {st }}\right.$ possibility)
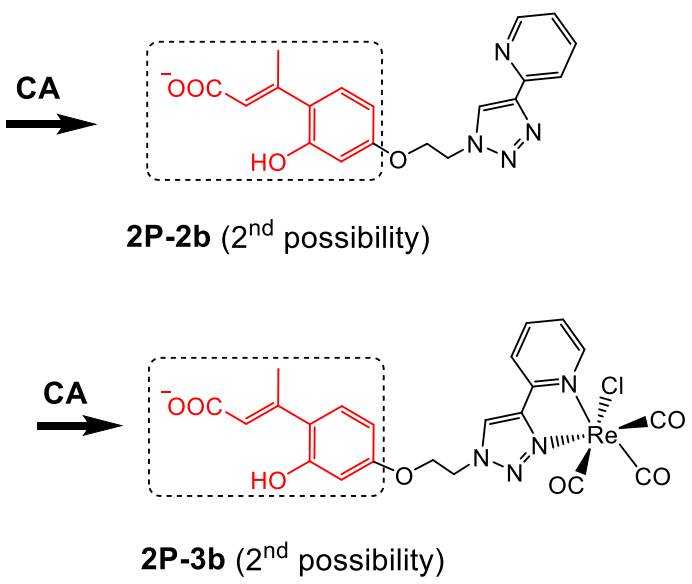

Figure 2. Coumarin compounds as CAIs $(\mathbf{1 A}, \mathbf{1 B}, \mathbf{1 P}-\mathbf{2} \mathbf{b}$ and $\mathbf{1 P}-\mathbf{3 b})$ and their hydrolysis products catalyzed by the CA enzyme (2A,2B,2P-2b and $\mathbf{2 P}-\mathbf{3 b})$. 


\subsubsection{Binding Mode Interactions of Sulfonamide Compounds 2a and 3a with hCA IX}

Both sulfonamide compounds, organic ligand 2a and its corresponding rhenium complex 3a, were docked into the same active hCA IX-pocket occupied by the native inhibitor (ligand ID: 9FK), and all rotational bonds were considered flexible. The top conformations generated for the docked ligands $2 \mathbf{a}$ and $\mathbf{3 a}$ in the hCA IX pocket were aligned and compared with the native ligand 9FK as illustrated in Figure 3. Generally, the binding mode obtained by docking for the two docked inhibitors $2 \mathbf{a} / 3 \mathbf{3}$ shows that the benzene-sulfonamide moiety resembles the binding mode of ligands found in the crystal structure of 9FK - hCA IX complex (PDB ID: 5FL4). The deprotonated nitrogen of the sulfonamide tail in both cases was located close to the zinc atom, and was similar to that of the native ligand. Similarly, the $\mathrm{Zn}-\mathrm{N}$ distance in the binding region of the CA-inhibitor complexes ranged between 2.18 and $2.25 \AA$ (Table S4 in Supplementary Information), values which are close to those reported for other CA-inhibitor complexes containing similar inhibitors (1.95-2.57 $\mathrm{A})$ [77].

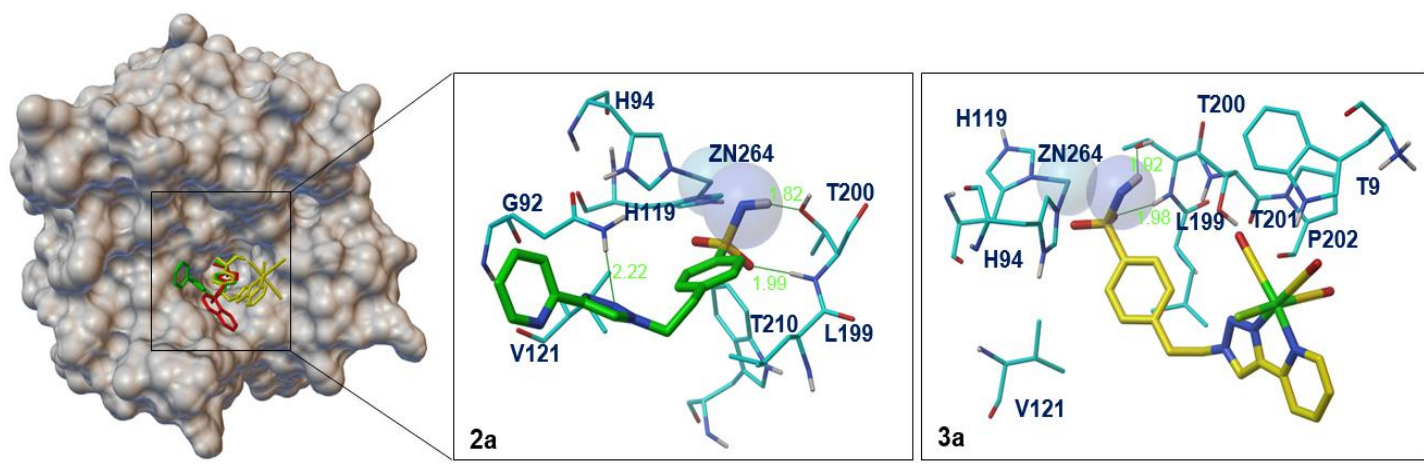

Figure 3. (Left): Alignments of the docked organic ligand 2a (green color) and its corresponding Re-complex 3a (yellow color) within binding site of the hCA IX target (PDB code: 5FL4), compared with the native sulfonamide ligand (red color). (Right): Representation of the active site of hCA IX isoform showing side chain residues participating in interactions with docked inhibitors (organic ligand $2 \mathrm{a}$ and its Re-complex 3a). The $\mathrm{Zn}-\mathrm{N}$ interaction is indicated with coordination spheres. $\mathrm{H}$-bonds are represented as green lines and their distances are on angstrom. Color Code: Carbon atoms in green (for $\mathbf{2 a}$ ), yellow (for 3a) and aquamarine (for side amino acid residues); oxygen atoms in red; nitrogen atoms in blue; sulfur atoms in yellow; chlorine and rhenium atoms in green.

Figure 3 reveals that inhibitors $\mathbf{2 a}$ and $\mathbf{3 a}$ were stabilized not only by H-bonding interactions, but also through several hydrophobic/hydrophilic interactions with side chain amino acid residues of the protein, depending on the chelate part of the inhibitors. For the metallic compound 3a, the nitrogen and oxygen atoms of the sulfonamide moiety formed two hydrogen bonds with Thr200 residue, while the aromatic ring formed hydrophobic interactions with the side chain Val121 and Leu199. Thus, the $-\mathrm{CH}_{2} \mathrm{CH}_{2}$ - linker, which made a weak hydrophobic interaction with the end of Leu199, seems to give more flexibility to the Re-compound, allowing the accommodation of the $f a c-\operatorname{Re}(\mathrm{CO})_{3}$ core near residues Thr201, Pro202 and Trp9. On the other hand, the best conformation of the organic compound 2a orients the arylsulfonamide moiety deep into the hCA IX binding cavity, in a similar mode to its corresponding metallic compound, forming three hydrogen bonds, two with the Thr200 residue and another one between the N-triazolyl atom and Gln92. This preferred conformation is chosen because of its shorter $\mathrm{Zn}-\mathrm{N}$ distance of $2.18 \AA$, the lowest mean binding energy of $-8.24 \mathrm{kcal} \mathrm{mol}^{-1}$, and favourable van der Waals interactions with the most important side residues (e.g., His119, Trp210, His94, Leu199, Val121, Gln92).

From the obtained results, we can suggest that the shorter $\mathrm{Zn}-\mathrm{N}$ distance and the additional H-bonding interaction, provided by the free triazolyl nitrogen of the pyta scaffold, reflect the nanomolar inhibition data found for the organic compound 2a against hCA-IX compared to its corresponding Re-based derivative $3 \mathbf{a}\left(K_{\mathrm{i}}(\mathbf{2 a})=11.7 \mathrm{nM}\right.$ vs. $\left.K_{\mathrm{i}}(3 \mathbf{a})=29.7 \mathrm{nM}\right)$. 


\subsubsection{Binding Mode Interactions of Coumarin Compounds $\mathbf{2} \mathbf{b}$ and $\mathbf{3 b}$ with hCA IX}

For the docked coumarin compounds $\mathbf{2 b} / \mathbf{3 b}$, only the open form (2P-2b and $\mathbf{2 P}-\mathbf{3 b}$, as highlighted in Figure 2) was discussed for each type within the hCA IX active site. According to Table S4 (Supplementary Information), the predicted hydrolyzed coumarinproducts have lowest mean binding energies, compared to their mimic closed forms, which means more flexibility for the 2-hydroxycinnamic acid moiety, and more interactions with the CA IX side residues.

For the hCA IX isoform, in vitro results showed that $\mathbf{3 b}$ exhibited a slight best inhibition compared to its organic derivative $2 \mathbf{b}\left(K_{\mathrm{i}}(3 \mathrm{~b})=34.9 \mathrm{nM}\right)$ vs. $\left.K_{\mathrm{i}}(\mathbf{2 b})=44.5 \mathrm{nM}\right)$. In the docking results, we also found that the $\mathbf{2} \mathbf{P}-\mathbf{3 b}$ (and/or its closed form $\mathbf{1 P -} \mathbf{3} \mathbf{b}$ ) compound has a promising docking score (Supplementary Information, Table S4).

In Figure 4, the top conformations generated for the docked hydrolyzed compounds $2 \mathbf{P}-2 \mathbf{b}$ and $\mathbf{2 P}-3 \mathbf{b}$ were superimposed in the same hCA IX binding pocket and then compared with the native inhibitor 2B (Ligand ID: TE1). Docking analysis shows that the open form of organic compound $\mathbf{2 P - 2 b}$, which allows for more direct interactions with the side residues, is linked by five H-bonds to residues Arg196, The205, Gln203 and Gln224. The side chain residues that are in close contact with 2P-2b are Arg194, Leu223 and Vall262 (see Figure 4). In other words, the hydrolyzed form of the metallic inhibitor $\mathbf{2 P - 3} \mathbf{b}$ shares a binding mode somewhat similar to that occupied by its organic mimic. In contrast, the metallic inhibitor $\mathbf{2 P}-\mathbf{3 b}$ exhibits additional polar/hydrophobic interactions between the fac- $\operatorname{Re}(\mathrm{CO})_{3}$ unit and some residues such as His200, Leu331, Pro334 and Pro335. We can also observe an additional interaction between residue Asn198 and 2-hydroxy-cinnamic acid moiety, which is absent in the corresponding organic compound $\mathbf{2} \mathbf{P}-\mathbf{2} \mathbf{b}$.

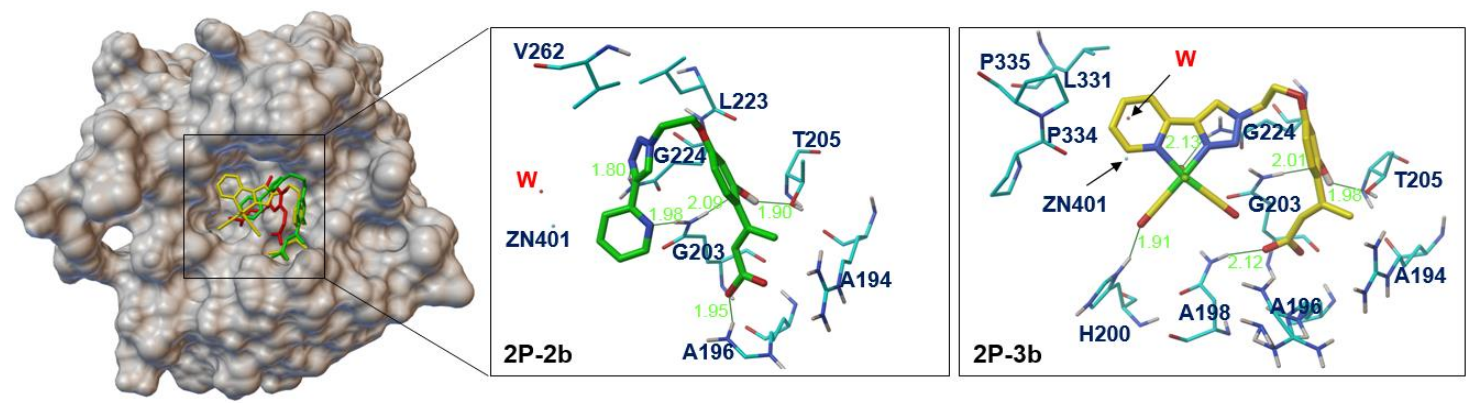

Figure 4. (Left): Alignments of the docked organic ligand 2P-2b (green color) and its corresponding Re-complex $\mathbf{2 P - 3 b}$ (yellow color) within the hCAIX (PDB code: 5DVX) binding site, compared with the native 2-hydroxycinnamic acid ligand (red color). (Right): Representation of the active site of hCA IX isoform showing side chain residues participating in interactions with docked inhibitors (organic ligand $\mathbf{2 P - 2 b}$ and its Re-complex $\mathbf{2 P - 3 b}$ ). H-bonds are represented as green lines and their distances are in angstrom. Water molecules $(\mathrm{w})$ are shown as red circles. Color Code: Carbon atoms in green (for $\mathbf{2 P - 2 b}$ ), yellow (for $\mathbf{2 P - 3 b}$ ) and aquamarine (for side amino acid residues); oxygen atoms in red; nitrogen atoms in blue; sulfur atoms in yellow; chlorine and rhenium atoms in green.

Furthermore, Figure 5 demonstrates that the increased affinity of the metallic compound $\mathbf{2 P - 3} \mathbf{b}$ towards hCA IX is clearly related to the molecule overall shape, where the contribution of $f a c-\operatorname{Re}(\mathrm{CO})_{3}$ head plays a very important role in filling the active site entrance. In contrast, the organic mimic $\mathbf{2} \mathbf{P}-\mathbf{2 b}$ provides an elongated form, resulting in a less bulky ligand which cannot interact efficiently with side chain residues of the active site pocket. 


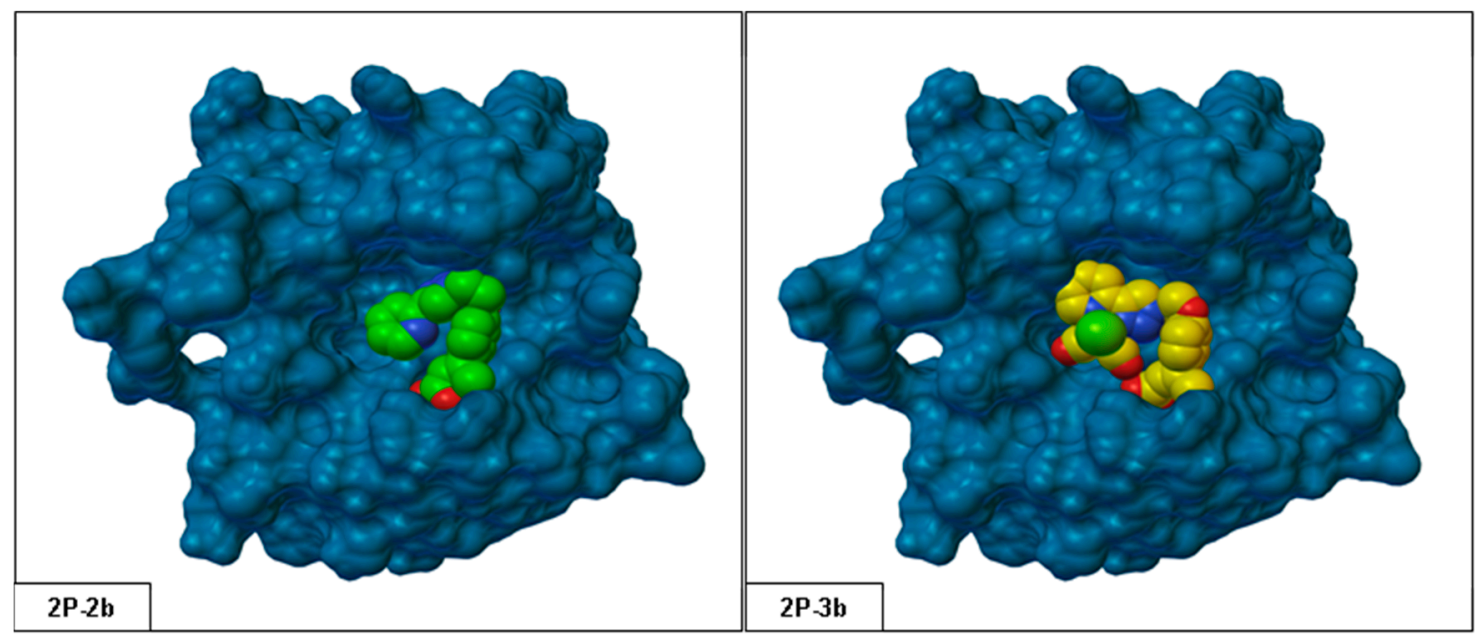

Figure 5. View of the shape complementarities between hCA-IX active site and $\mathbf{2 P - 2 b}$ (left) and $\mathbf{2 P - 3 b}$ (right). The inhibitor atoms are shown as spheres and the enzyme is represented as a surface-model. Color Code: Carbon atoms in green (for $\mathbf{2 P - 2 b}$ ), yellow (for 2P-3b); oxygen atoms in red; nitrogen atoms in blue; sulfur atoms in yellow; chlorine and rhenium atoms in green.

\section{Conclusions}

In brief, we report here the synthesis of two new pyridyl-triazole derivatives containing sulfonamide/coumarin moieties and their corresponding rhenium complexes as potent carbonic anhydrase inhibitors. All the newly synthetized compounds using a click chemistry strategy were fully characterized in solution (IR, NMR, MS) and solid state (X-ray). All bond length and angle values are in line with those reported for other pyta ligands and their corresponding rhenium complexes. In addition, the ethylene bridge keeps the sulfonamide or coumarin group at a large distance from the chelating part of the molecule, and prevents the folding of the pendant arm towards the metal centre, as expected.

The four compounds showed selective inhibitory activity in the high nanomolar range against both tumour-associated isoforms hCA IX and hCA XII $\left(K_{\mathrm{i}}\right.$ values range from $9.8 \mathrm{nM}$ to $44.5 \mathrm{nM}$ ). In terms of selectivity, coumarin derivative $\mathbf{2} \mathbf{b}$ and $\mathbf{3 b}$ showed high selectivities against hCA IX and hCA XII compared to the off-target isoforms hCA I and hCA II (ratio hCA I or hCA II/hCA IX range of 225 (2b) and $287(3 \mathbf{b})$ and ratio hCA I or hCA II/hCA XII of $787(\mathbf{2 b})$ and $315(\mathbf{3 b})$ ). Despite this slight decrease in affinity against hCA XII, $\mathbf{3 b}$ seems more promising than $\mathbf{2 b}$ because of its potential use as an imaging agent (with its technetium-99m analogue) for the in vivo detection of cancer.

The biological results obtained here are well rationalized by the molecular docking studies (for hCA IX). For the sulfonamide derivatives, the additional H-bonding and van der Waals interactions provided by the two (free) nitrogens of the pyta unit explain the stronger inhibition of 2a against hCA IX compared to its corresponding metallic complex 3a. In contrast, the docking simulation revealed that coumarin-based rhenium complex $3 \mathbf{b}$ (in its hydrolyzed form 2P-3b) exhibited greater inhibition against hCA IX than its ligand $\mathbf{2 b}$, due to the 3-dimensional architecture of the molecule, where the bulky of $f a c-\operatorname{Re}(\mathrm{CO})_{3}$ head plays a very important role in filling the active site entrance. This finding is very encouraging for further developments in the field of rhenium(I) complexes of coumarin with CA inhibitory action. However, while the data (in vitro study and predictive docking experiments) indicated that $\mathbf{3 b}$ may be promising drug candidate, further biochemical research is required to establish the efficacy of this compound prior to further steps. In vivo studies will be conducted in the near future to obtain more information about its inhibitory power and cytotoxicity.

Supplementary Materials: The following are available online at https:/ / www.mdpi.com/article/10 $.3390 /$ cryst11091076/s1, Table S1: Selected experimental bond lengths $[\AA]$ and angles $\left[{ }^{\circ}\right.$ ] for $2 \mathbf{a}$ and $\mathbf{2 b}$, Table S2: Selected experimental bond lengths $[\AA]$ and angles $\left[{ }^{\circ}\right]$ for $\mathbf{3 a}$ and $\mathbf{3 b}$, Table S3: Hydrogen 
bonds for $\mathbf{2 a}, \mathbf{2 b}, \mathbf{3 a}$ and $\mathbf{3 b}\left[\AA\right.$ and $^{\circ}$ ], Table S4: Estimated free energy of binding (Kcal mol $\left.{ }^{-1}\right), \mathrm{H}^{-}$ bond interactions number and $\mathrm{Zn}-\mathrm{N}$ distances $(\AA)$ in the interaction region of the HCA IX-inhibitor complexes, Figure S1: Alignment of isoforms IX of hCA (pdb codes: $5 \mathrm{fl} 4$ and 5dvx) within the active site of hCA II (pdb code: 3f8e), Figure S2: Molecular views of 2a (top) and $2 \mathbf{b}$ (bottom) with 50\% ellipsoidal probability; hydrogen atoms have been omitted for clarity, except H on N5 atom (2a).

Author Contributions: Synthesis and analytical characterization, Y.A., R.E. and E.B.; Crystallographic study, N.S.-M. and S.M.-L.; Biological study, J.-Y.W., A.N. and C.T.S.; Docking study, F.R. and A.S.; writing-original draft preparation, E.B. and A.S. All authors have read and agreed to the published version of the manuscript.

Funding: This research received no external funding.

Data Availability Statement: Not applicable.

Acknowledgments: This work was supported in part by The General Directorate of Scientific Research and Technological Development (DGRSDT). The authors gratefully acknowledge the Algerian Ministry of Higher Education and Scientific Research (MESRS) for financial support through PRFU project B00L01UN240120190001.

Conflicts of Interest: The authors declare no conflict of interest.

\section{References}

1. Kurt, B.Z.; Sonmez, F.; Öztürk, D.; Akdemir, A.; Angeli, A.; Supuran, C.T. Synthesis of coumarin-sulfonamide derivatives and determination of their cytotoxicity, carbonic anhydrase inhibitory and molecular docking studies. Eur. J. Med. Chem. 2019, 183, 111702. [CrossRef]

2. Angeli, A.; Carta, F.; Nocentini, A.; Winum, J.Y.; Zalubovskis, R.; Akdemir, A.; Onnis, V.; Eldehna, W.M.; Capasso, C.; Simone, G.; et al. Carbonic Anhydrase Inhibitors Targeting Metabolism and Tumor Microenvironment. Metabolites 2020, 10, 412. [CrossRef] [PubMed]

3. Lou, Y.; McDonald, P.C.; Oloumi, A.; Chia, S.; Ostlund, C.; Ahmadi, A.; Kyle, A.; Auf dem Keller, U.; Leung, S.; Huntsman, D.; et al. Targeting tumor hypoxia: Suppression of breast tumor growth and metastasis by novel carbonic anhydrase IX inhibitors. Cancer Res. 2011, 71, 3364-3376. [CrossRef]

4. Lock, F.E.; McDonald, P.C.; Lou, Y.; Serrano, I.; Chafe, S.C.; Ostlund, C.; Aparicio, S.; Winum, J.Y.; Supuran, C.T.; Dedhar, S. Targeting carbonic anhydrase IX depletes breast cancer stem cells within the hypoxic niche. Oncogene 2013, 31-32, 5210-5219. [CrossRef]

5. Supuran, C.T. Carbonic anhydrase inhibitors as emerging agents for the treatment and imaging of hypoxic tumors. Expert Opin. Investig. Drugs 2018, 27, 963-970. [CrossRef]

6. Giosuè, C.; Maruca, A.; Rocca, R.; Ambrosio, F.A.; Berrino, E.; Carta, F.; Mesiti, F.; Salatino, A.; Lanzillotta, D.; Trapasso, F.; et al. In silico identification and biological evaluation of antioxidant food components endowed with IX and XII hCA inhibition. Antioxidants 2020, 9, 775.

7. Peperidou, A.; Bua, S.; Bozdag, M.; Hadjipavlou-Litina, D.; Supuran, C.T. Novel 6-and 7-substituted coumarins with inhibitory action against lipoxygenase and tumor-associated carbonic anhydrase IX. Molecules 2018, 23, 153. [CrossRef]

8. Goud Narella, S.; Ghouse Shaik, M.; Mohammed, A.; Alvala, M.; Angeli, A.; Supuran, C.T. Synthesis and biological evaluation of coumarin-1,3,4-oxadiazole hybrids as selective carbonic anhydrase IX and XII inhibitors. Bioorg. Chem. 2019, 87, 765-772. [CrossRef] [PubMed]

9. Grandane, A.; Tanc, M.; Di Cesare Mannelli, L.; Carta, F.; Ghelardini, C.; Žalubovskis, R.; Supuran, C.T. 6-Substituted sulfocoumarins are selective carbonic anhdydrase IX and XII inhibitors with significant cytotoxicity against colorectal cancer cells. J. Med. Chem. 2015, 58, 3975-3983. [CrossRef]

10. Nocentini, A.; Moi, D.; Deplano, A.; Osman, S.M.; AlOthman, Z.A.; Balboni, G.; Supuran, C.T.; Onnis, V. Sulfonamide/sulfamate switch with a series of piperazinylureido derivatives: Synthesis, kinetic and in silico evaluation as carbonic anhydrase isoforms I, II, IV, and IX inhibitors. Eur. J. Med. Chem. 2020, 186, 111896. [CrossRef] [PubMed]

11. Li, F.R.; Fan, Z.F.; Qi, S.J.; Wang, Y.S.; Wang, J.; Liu, Y.; Cheng, M.S. Design, synthesis, molecular docking analysis, and carbonic anhydrase IX inhibitory evaluations of novel $N$-substituted- $\beta$-D-glucosamine derivatives that incorporate benzenesulfonamides. Molecules 2017, 22, 785. [CrossRef] [PubMed]

12. Ramya, P.V.S.; Angapelly, S.; Angeli, A.; Singh Digwal, C.; Arifuddin, M.; Nagendra Babu, B.; Supuran, C.T.; Kamal, K. Discovery of curcumin inspired sulfonamide derivatives as a new class of carbonic anhydrase isoforms I, II, IX, and XII inhibitors. J. Enzym. Inhib. Med. Chem. 2017, 32, 1274-1281. [CrossRef]

13. Jiang, C.; Shi, J.; Liao, L.; Zhang, L.; Liu, J.; Wang, Y.; Lao, Y.; Zhang, J. 5-[2-(N-(Substituted phenyl) acetamide)] amino-1,3,4thiadiazole-2-sulfonamides as Selective Carbonic Anhydrase II Inhibitors with Neuroprotective Effects. ChemMedChem 2020, 15, 705-715. [CrossRef] 
14. Bruno, E.; Buemi, M.R.; Di Fiore, A.; De Luca, L.; Ferro, S.; Angeli, A.; Cirilli, R.; Sadutto, D.; Alterio, V.; Monti, S.M.; et al. Probing molecular interactions between human carbonic anhydrases (hCAs) and a novel class of benzenesulfonamides. J. Med. Chem. 2017, 60, 4316-4326. [CrossRef] [PubMed]

15. Ceni, C.; Catarzi, D.; Varano, F.; DalBen, D.; Marucci, G.; Buccioni, M.; Volpini, R.; Angeli, A.; Nocentini, A.; Gratteri, P.; et al. Discovery of first-in-class multi-target adenosine A2A receptor antagonists-carbonic anhydrase IX and XII inhibitors. 8-Amino-6-aryl-2-phenyl-1,2,4-triazolo [4,3-a] pyrazin-3-one derivatives as new potential antitumor agents. Eur. J. Med. Chem. 2020, 201, 112478. [CrossRef] [PubMed]

16. Halawa, A.H.; Elgammal, W.E.; Hassan, S.M.; Hassan, A.H.; Nassar, H.S.; Ebrahim, H.Y.; Mehany, A.B.M.; El-Agrody, A.M. Synthesis, anticancer evaluation and molecular docking studies of new heterocycles linked to sulfonamide moiety as novel human topoisomerase types I and II poisons. Bioorg. Chem. 2020, 98, 103725. [CrossRef] [PubMed]

17. Alterio, V.; Di Fiore, A.; D'Ambrosio, K.; Supuran, C.T.; De Simone, G. Multiple binding modes of inhibitors to carbonic anhydrases: How to design specific drugs targeting 15 different isoforms? Chem. Rev. 2012, 112, 4421-4468. [CrossRef]

18. Grüner, B.; Kugler, M.; El Anwar, S.; Holub, J.; Nekvinda, J.; Bavol, D.; Růžičková, Z.; Pospíšilová, K.; Fábry, M.; Král, V.; et al. Cobalt Bis (dicarbollide) Alkylsulfonamides: Potent and Highly Selective Inhibitors of Tumor Specific Carbonic Anhydrase IX. ChemPlusChem 2021, 86, 352-363. [CrossRef] [PubMed]

19. Serše, S.; Traven, K.; Kljun, J.; Turel, I.; Supuran, C.T. Organoruthenium(II) complexes of acetazolamide potently inhibit human carbonic anhydrase isoforms I, II, IX and XII. J. Enzym. Inhib. Med. Chem. 2019, 34, 388-393. [CrossRef]

20. Huentupil, Y.; Peña, L.; Novoa, N.; Berrino, E.; Arancibia, R.; Supuran, C.T. New sulfonamides containing organometallicacylhydrazones: Synthesis, characterisation and biological evaluation as inhibitors of human carbonic anhydrases. J. Enzym. Inhib. Med. Chem. 2019, 34, 451-458. [CrossRef]

21. Brichet, J.; Arancibia, R.; Berrino, E.; Supuran, C.T. Bioorganometallic derivatives of 4-hydrazino-benzenesulphonamide as carbonic anhydrase inhibitors: Synthesis, characterisation and biological evaluation. J. Enzym. Inhib. Med. Chem. 2020, 35, 622-628. [CrossRef] [PubMed]

22. Cao, Q.; Zhou, D.-J.; Pan, Z.-Y.; Yang, G.-G.; Zhang, H.; Ji, L.N.; Mao, Z.-W. CAIXplatins: Highly potent Pt(IV) prodrugs selectively against hypoxic tumors via microenvironment and metabolism regulation. Angew. Chem. Int. Ed. 2020, 59, 1855618562. [CrossRef]

23. Can, D.; Spingler, B.; Schmutz, P.; Mendes, F.; Raposinho, P.; Fernandes, C.; Carta, F.; Innocenti, A.; Santos, I.; Supuran, C.T.; et al. $\left[(\mathrm{Cp}-\mathrm{R}) \mathrm{M}(\mathrm{CO})_{3}\right]\left(\mathrm{M}=\mathrm{Re}\right.$ or $\left.{ }^{99 \mathrm{~m}} \mathrm{Tc}\right)$ Arylsulfonamide, arylsulfamide, and arylsulfamate conjugates for selective targeting of human carbonic anhydrase IX. Angew. Chem. Int. Ed. 2012, 51, 3354-3357. [CrossRef]

24. Aimene, Y.; Eychenne, R.; Mallet-Ladeira, S.; Saffon, N.; Winum, J.-Y.; Nocentini, A.; Supuran, C.T.; Benoist, E.; Seridi, A. Novel Re (I) tricarbonyl coordination compounds based on 2-pyridyl-1, 2, 3-triazole derivatives bearing a 4-amino-substituted benzenesulfonamide arm: Synthesis, crystal structure, computational studies and inhibitory activity against carbonic anhydrase I, II, and IX isoforms. J. Enzym. Inhib. Med. Chem. 2019, 34, 773-778.

25. De Luca, L.; Mancuso, F.; Ferro, S.; Buemi, M.R.; Angeli, A.; Del Prete, S.; Capasso, C.; Supuran, C.T.; Gitto, R. Inhibitory effects and structural insights for a novel series of coumarin-based compounds that selectively target human CA IX and CA XII carbonic anhydrases. Eur. J. Med. Chem. 2018, 143, 276-282. [CrossRef]

26. Bonardi, A.; Falsini, M.; Catarzi, D.; Varano, F.; Mannelli, L.D.C.; Tenci, B.; Ghelardini, C.; Angeli, A.; Supuran, C.T.; Colotta, V. Structural investigations on coumarins leading to chromeno [4,3-c] pyrazol-4-ones and pyrano [4,3-c] pyrazol-4-ones: New scaffolds for the design of the tumor-associated carbonic anhydrase isoforms IX and XII. Eur. J. Med. Chem. 2018, 146, 47-59. [CrossRef]

27. Kurt, B.Z.; Sonmez, F.; Durdagi, S.; Aksoydan, B.; Salmas, R.E.; Angeli, A.; Kucukislamoglu, M.; Supuran, C.T. Synthesis, biological activity and multiscale molecular modeling studies for coumaryl-carboxamide derivatives as selective carbonic anhydrase IX inhibitors. J. Enzyme Inhib. Med. Chem. 2017, 32, 1042-1052. [CrossRef]

28. Swain, B.; Angeli, A.; Singh, P.; Supuran, C.T.; Arifuddin, M. New coumarin/sulfocoumarin linked phenylacrylamides as selective transmembrane carbonic anhydrase inhibitors: Synthesis and in-vitro biological evaluation. Bioorg. Med. Chem. 2020, 28, 115586. [CrossRef] [PubMed]

29. Supuran, C.T.; Alterio, V.; Di Fiore, A.; D’ Ambrosio, K.; Carta, F.; Monti, S.M.; De Simone, G. Inhibition of carbonic anhydrase IX targets primary tumors, metastases, and cancer stem cells: Three for the price of one. Med. Res. Rev. 2018, 38, 1799-1836. [CrossRef] [PubMed]

30. Maresca, A.; Temperini, C.; Vu, H.; Pham, N.B.; Poulsen, S.A.; Scozzafava, A.; Quinn, R.J.; Supuran, C.T. Non-zinc mediated inhibition of carbonic anhydrases: Coumarins are a new class of suicide inhibitors. J. Am. Chem. Soc. 2009, 131, 3057-3062. [CrossRef] [PubMed]

31. Maresca, A.; Supuran, C.T. Coumarins incorporating hydroxy-and chloro-moieties selectively inhibit the transmembrane, tumorassociated carbonic anhydrase isoforms IX and XII over the cytosolic ones I and II. Bioorg. Med. Chem. Lett. 2010, 20, 4511-4514. [CrossRef] [PubMed]

32. Maresca, A.; Temperini, C.; Pochet, L.; Masereel, B.; Scozzafava, A.; Supuran, C.T. Deciphering the mechanism of carbonic anhydrase inhibition with coumarins and thiocoumarins. J. Med. Chem. 2010, 53, 335-344. [CrossRef] [PubMed]

33. Chambers, J.M.; Hill, P.A.; Aaron, J.A.; Han, Z.; Christianson, D.W.; Kuzma, N.M.; Dmochowski, I.J. Cryptophane xenon-129 nuclear magnetic resonance biosensors targeting human carbonic anhydrase. J. Am. Chem. Soc. 2009, 131, 563-569. [CrossRef] 
34. Duan, Y.-C.; Ma, Y.-C.; Zhang, E.; Shi, X.-J.; Wang, M.-M.; Ye, X.-W.; Liu, H.M. Design and synthesis of novel 1, 2, 3-triazoledithiocarbamate hybrids as potential anticancer agents. Eur. J. Med. Chem. 2013, 62, 11-19. [CrossRef]

35. Sheldrick, G.M. Integrated space-group and crystal-structure determination. Acta Cryst. A 2015, 71, 3-8. [CrossRef] [PubMed]

36. Sheldrick, G.M. Crystal structure refinement with SHELXL. Acta Cryst. C 2015, 71, 3-8. [CrossRef]

37. Khalifah, R.G. The carbon dioxide hydration activity of carbonic anhydrase. I. Stop-flow kinetic studies on the native human isoenzymes B and C. J. Biol. Chem. 1971, 246, 2561-2573. [CrossRef]

38. Sharma, A.; Tiwari, M.; Supuran, C.T. Novel coumarins and benzocoumarins acting as isoform-selective inhibitors against the tumor-associated carbonic anhydrase IX. J. Enzym. Inhib. Med. Chem. 2014, 29, 292-296. [CrossRef]

39. Durdagi, S.; Scozzafava, G.; Vullo, D.; Sahin, H.; Kolayli, S.; Supuran, C.T. Inhibition of mammalian carbonic anhydrases I-XIV with grayanotoxin III: Solution and in silico studies. J. Enzym. Inhib. Med. Chem. 2014, 29, 469-475. [CrossRef]

40. Alterio, V.; Hilvo, M.; Di Fiore, A.; Supuran, C.T.; Pan, P.; Parkkila, S.; Scaloni, A.; Pastorek, J.; Pastorekova, S.; Pedone, C.; et al. Crystal structure of the catalytic domain of the tumor-associated human carbonic anhydrase IX. Proc. Natl. Acad. Sci. USA 2009, 106, 16233-16238. [CrossRef]

41. La Regina, G.; Coluccia, A.; Famiglini, V.; Pelliccia, S.; Monti, L.; Vullo, D.; Nuti, E.; Alterio, V.; De Simone, G.; Monti, S.M.; et al. Discovery of $1,1^{\prime}$-biphenyl-4-sulfonamides as a new class of potent and selective carbonic anhydrase XIV inhibitors. J. Med. Chem. 2015, 58, 8564-8572. [CrossRef] [PubMed]

42. Nocentini, A.; Supuran, C.T. Advances in the structural annotation of human carbonic anhydrases and impact on future drug discovery. Expert Opin. Drug Discov. 2019, 14, 1175-1197. [CrossRef]

43. Leitans, J.; Kazaks, A.; Balode, A.; Ivanova, J.; Zalubovskis, R.; Supuran, C.T.; Tars, K. Efficient expression and crystallization system of cancer-associated carbonic anhydrase isoform IX. J. Med. Chem. 2015, 58, 9004-9009. [CrossRef]

44. Mahon, B.P.; Bhatt, A.; Socorro, L.; Driscoll, J.M.; Okoh, C.; Lomelino, C.L.; Mboge, M.Y.; Kurian, J.J.; Tu, C.; Agbandje-McKenna, M.; et al. The structure of carbonic anhydrase IX is adapted for low-pH catalysis. Biochemistry 2016, 55, 4642-4653. [CrossRef]

45. Biovia, D.S. Discovery Studio Modeling Environment, Version 2.5. BIOVIA Workbook, Release 2017; BIOVIA Pipeline Pilot; Dassault Systèmes: San Diego, CA, USA, 2017.

46. Pettersen, E.F.; Goddard, T.D.; Huang, C.C.; Couch, G.S.; Greenblatt, D.M.; Meng, E.C.; Ferrin, T.E. UCSF Chimera-A visualization system for exploratory research and analysis. J. Comput. Chem. 2004, 25, 1605-1612. [CrossRef]

47. Morris, G.M.; Goodsell, D.S.; Halliday, R.S.; Huey, R.; Hart, W.E.; Belew, R.K.; Olson, A.J. Automated docking using a Lamarckian genetic algorithm and anempirical binding free energy function. J. Comput. Chem. 1998, 19, 1639-1662. [CrossRef]

48. Morris, G.M.; Huey, R.; Lindstrom, W.; Sanner, M.F.; Belew, R.K.; Goodsell, D.S.; Olson, A.J. AutoDock4 and AutoDockTools4: Automated docking with selective receptor flexibility. J. Comput. Chem. 2009, 30, 2785-2791. [CrossRef]

49. Frisch, M.J.; Trucks, G.W.; Schlegel, H.B.; Scuseria, G.E.; Robb, M.A.; Cheeseman, J.R.; Scalmani, G.; Barone, V.; Mennucci, B.; Petersson, G.A.; et al. Gaussian 09, Revision A.02; Gaussian, Inc.: Wallingford, CT, USA, 2009.

50. Bouchouit, M.; Bouacida, S.; Zouchoune, B.; Merazig, H.; Bua, S.; Bouaziz, Z.; Le Borgne, M.; Supuran, C.T.; Bouraiou, A. Synthesis, X-ray structure, in silico calculation, and carbonic anhydrase inhibitory properties of benzylimidazole metal complexes. J. Enzym. Inhib. Med. Chem. 2018, 33, 1150-1159. [CrossRef]

51. Lee, C.; Yang, W.; Parr, R.G. Development of the Colle-Salvetti correlation-energy formula into a functional of the electron density. Phys. Rev. B 1988, 37, 785. [CrossRef] [PubMed]

52. Becke, A.D. Density-functional thermochemistry. III. The role of exact exchange. J. Chem. Phys. 1993, 98, 5648-5652. [CrossRef]

53. Dennington, R.; Keith, T.; Milliam, J. GaussView Version 4.1.2; Semichem Inc.: Shawnee Mission, KS, USA, 2007.

54. Obata, M.; Kitamura, A.; Mori, A.; Kameyama, C.; Czaplewska, J.A.; Tanaka, R.; Kinoshita, I.; Kusumoto, T.; Hashimoto, H.; Harada, M.; et al. Syntheses, structural characterization and photophysical properties of 4-(2-pyridyl)-1, 2, 3-triazole rhenium(I) complexes. Dalton Trans. 2008, 25, 3292-3300. [CrossRef] [PubMed]

55. Schweinfurth, D.; Pattacini, R.; Strobel, S.; Sarkar, B. New 1,2,3-triazole ligands through click reactions and their palladium and platinum complexes. Dalton Trans. 2009, 9291-9297. [CrossRef] [PubMed]

56. Crowley, J.D.; Bandeen, P.H. A multicomponent CuAAC "click" approach to a library of hybrid polydentate 2-pyridyl-1,2,3triazole ligands: New building blocks for the generation of metallosupramolecular architectures. Dalton Trans. 2010, 39, 612-623. [CrossRef]

57. Kilpin, K.J.; Gavey, E.L.; McAdam, C.J.; Anderson, C.B.; Lind, S.J.; Keep, C.C.; Gordon, K.C.; Crowley, J.D. Palladium(II) Complexes of readily functionalized bidentate 2-Pyridyl-1,2,3-triazole "click" ligands: A synthetic, structural, spectroscopic, and computational study. Inorg. Chem. 2011, 50, 6334-6346. [CrossRef]

58. Clède, S.; Lambert, F.; Sandt, C.; Gueroui, Z.; Réfrégiers, M.; Plamont, M.A.; Dumas, P.; Vessières, A.; Policar, C. A rhenium tris-carbonyl derivative as a single core multimodal probe for imaging (SCOMPI) combining infrared and luminescent properties. Chem. Commun. 2012, 48, 7729-7731. [CrossRef] [PubMed]

59. Bertrand, H.C.; Clède, S.; Guillot, R.; Lambert, F.; Policar, C. Luminescence modulations of rhenium tricarbonyl complexes induced by structural variations. Inorg. Chem. 2014, 53, 6204-6223. [CrossRef] [PubMed]

60. Seridi, A.; Wolff, M.; Boulay, A.; Saffon, N.; Coulais, Y.; Picard, C.; Machura, B.; Benoist, E. Rhenium(I) and technetium(I) complexes of a novel pyridyltriazole-based ligand containing an arylpiperazine pharmacophore: Synthesis, crystal structures, computational studies and radiochemistry. Inorg. Chem. Commun. 2011, 14, 238-242. [CrossRef] 
61. Wolff, M.; Munoz, L.; François, A.; Carrayon, C.; Seridi, A.; Saffon, N.; Picard, C.; Machura, B.; Benoist, E. Tricarbonylrhenium complexes from 2-pyridyl-1, 2, 3-triazole ligands bearing a 4-substituted phenyl arm: A combined experimental and theoretical study. Dalton Trans. 2013, 42, 7019-7031. [CrossRef]

62. François, A.; Auzanneau, C.; Le Morvan, V.; Galaup, C.; Godfrey, H.S.; Marty, L.; Boulay, A.; Artigau, M.; Mestre-Voegtlé, B.; Leygue, N.; et al. A functionalized heterobimetallic $99 \mathrm{mTc} /$ Re complex as a potential dual-modality imaging probe: Synthesis, photophysical properties, cytotoxicity and cellular imaging investigations. Dalton Trans. 2014, 43, 439-450. [CrossRef]

63. Wang, J.; Delavaux-Nicot, B.; Wolff, M.; Mallet-Ladeira, S.; Métivier, R.; Benoist, E.; Fery-Forgues, S. The Unsuspected Influence of the Pyridyl-Triazole Ligand Isomerism upon the Electronic Properties of Tricarbonyl Rhenium Complexes: An Experimental and Theoretical Insight. Dalton Trans. 2018, 47, 8087-8099. [CrossRef]

64. Mindt, T.L.; Struthers, H.; Brans, L.; Anguelov, T.; Schweinsberg, C.; Maes, V.; Tourwé, D.; Schibli, R. “Click to chelate”: Synthesis and installation of metal chelates into biomolecules in a single step. J. Am. Chem. Soc. 2006, 128, 15096-15097. [CrossRef] [PubMed]

65. Struthers, H.; Mindt, T.L.; Schibli, R. Metal chelating systems synthesized using the copper(I) catalyzed azide-alkynecycloaddition. Dalton Trans. 2010, 39, 675-696. [CrossRef]

66. Said, M.A.; Eldehna, W.M.; Nocentini, A.; Bonardi, A.; Fahim, S.H.; Bua, S.; Soliman, D.H.; Abdel-Aziz, H.A.; Gratteri, P.; AbouSer, S.M.; et al. Synthesis, biological and molecular dynamics investigations with a series of triazolopyrimidine/triazole-based benzenesulfonamides as novel carbonic anhydrase inhibitors. Eur. J. Med. Chem. 2020, 185, 111843. [CrossRef] [PubMed]

67. Swain, B.; Angeli, A.; Angapelly, S.; Thacker, P.S.; Singh, P.; Supuran, C.T.; Arifuddin, M. Synthesis of a new series of 3functionalised-1-phenyl-1, 2, 3-triazole sulfamoylbenzamides as carbonic anhydrase I, II, IV and IX inhibitors. J. Enzym. Inhib. Med. Chem. 2019, 34, 1199-1209. [CrossRef]

68. Kumar, R.; Sharma, V.; Bua, S.; Supuran, C.T.; Sharma, P.K. Synthesis and biological evaluation of benzenesulphonamide-bearing 1, 4, 5-trisubstituted-1, 2, 3-triazoles possessing human carbonic anhydrase I, II, IV, and IX inhibitory activity. J. Enzym. Inhib. Med. Chem. 2017, 32, 1187-1194. [CrossRef]

69. Sepehri, N.; Mohammadi-Khanaposhtani, M.; Asemanipoor, N.; Hosseini, S.; Biglar, M.; Larijani, B.; Mahdavi, M.; Hamedifar, H.; Taslimi, P.; Sadeghian, N.; et al. Synthesis, characterization, molecular docking, and biological activities of coumarin-1, 2, 3-triazole-acetamide hybrid derivatives. Arch. Pharm. 2020, 353, e2000109. [CrossRef] [PubMed]

70. Kurt, B.Z.; Dag, A.; Doğan, B.; Durdagi, S.; Angeli, A.; Nocentini, A.; Supuran, C.T.; Sonmez, F. Synthesis, biological activity and multiscale molecular modeling studies of bis-coumarins as selective carbonic anhydrase IX and XII inhibitors with effective cytotoxicity against hepatocellular carcinoma. Bioorg. Chem. 2019, 87, 838-850. [CrossRef] [PubMed]

71. Nocentini, A.; Carta, F.; Ceruso, M.; Bartolucci, G.; Supuran, C.T. Click-tailed coumarins with potent and selective inhibitory action against the tumor-associated carbonic anhydrases IX and XII. Bioorg. Med. Chem. 2015, 23, 6955-6966. [CrossRef] [PubMed]

72. Salmon, A.J.; Williams, M.L.; Wu, Q.K.; Morizzi, J.; Gregg, D.; Charman, S.A.; Vullo, D.; Supuran, C.T.; Poulsen, S.-A. Metallocenebased inhibitors of cancer-associated carbonic anhydrase enzymes IX and XII. J. Med. Chem. 2012, 55, 5506-5517. [CrossRef] [PubMed]

73. Misaki, N.; Pan, J.; Lin, K.-S.; Thompson, J.R.; Nocentini, A.; Supuran, C.T.; Nakabayashi, Y.; Storr, T. Evaluation of 99m Tcsulfonamide and sulfocoumarin derivatives for imaging carbonic anhydrase IX expression. J. Inorg. Biochem. 2018, 185, 63-70.

74. Suntrup, L.; Klenk, S.; Klein, J.; Sobottka, S.; Sarkar, B. Gauging Donor/Acceptor Properties and Redox Stability of Chelating Click-Derived Triazoles and Triazolylidenes: A Case Study with Rhenium(I) Complexes. Inorg. Chem. 2017, 56, 5771-5783. [CrossRef] [PubMed]

75. Akurathi, V.; Dubois, L.; Lieuwes, N.G.; Chitneni, S.K.; Cleynhens, B.J.; Vullo, D.; Supuran, C.T.; Verbruggen, A.M.; Lambin, P.; Bormans, G.M. Synthesis and biological evaluation of a ${ }^{99 \mathrm{~m}} \mathrm{Tc}-$ labelled sulfonamide conjugate for in vivo visualization of carbonic anhydrase IX expression in tumor hypoxia. Nucl. Med. Biol. 2010, 37, 557-564. [CrossRef] [PubMed]

76. Lu, G.; Hillier, S.M.; Maresca, K.P.; Zimmerman, C.N.; Eckelman, W.C.; Joyal, J.L.; Babich, J.W. Synthesis and SAR of novel $\mathrm{Re} /{ }^{99 \mathrm{~m}} \mathrm{Tc}-$ labeled benzenesulfonamide carbonic anhydrase IX inhibitors for molecular imaging of tumor hypoxia. J. Med. Chem. 2013, 56, 510-520. [CrossRef] [PubMed]

77. Samanta, P.N.; Das, K.K. Prediction of binding modes and affinities of 4-substituted-2,3,5,6-tetrafluorobenzenesulfonamide inhibitors to the carbonic anhydrase receptor by docking and ONIOM calculations. J. Mol. Graph. Model. 2016, 63, 38-48. [CrossRef] [PubMed] 